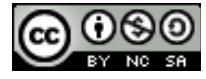

https://doi.org/10.31743/abmk.13260

\author{
ANNA SEWERYN* - KRAKÓW
}

\title{
FOTOGRAFIA W ARCHIWUM. IDENTYFIKACJA - ZABEZPIECZANIE - KONSERWACJA
}

\section{Streszczenie}

Artykuł poświecony jest zagadnieniu fotografii jako materiału archiwalnego wymagającego szczególnej wiedzy na etapie identyfikacji, zabezpieczania i konserwacji zbiorów. Fotografie to obiekty wykonane w różnorodnych technikach i technologiach, na bazie rozlicznych podłoży i substancji światłoczułych. Ich skomplikowana budowa odpowiedzialna jest za wyjątkową wrażliwość obiektów w kontakcie z czynnikami niszczącymi oraz często gwałtowny przebieg procesu degradacji, kończący się nawet całkowitą utratą nośnika. Tekst porusza problematykę identyfikacji technik i technologii wykonania obiektów, opisuje czynniki wpływając na degradację zdjęć, a także podkreśla podstawowe wytyczne do zabezpieczania oraz konserwacji zbiorów.

Przedstawione zostały również początki powstawania zjawiska fotografii, jak i najczęściej występujące w zbiorach polskich techniki fotograficzne. Autorka opisuje najważniejsze badania dotyczące identyfikacji i zabezpieczania fotografii wraz z podaniem materiałów źródłowych.

Zasadniczą częścią opracowania są wytyczne dotyczące procesu identyfikacji techniki wykonania obiektu, od którego należy rozpocząć wszelkie działania odnoszące się do zabezpieczenia czy konserwowania fotografii (w tym identyfikacja nietrwałych podłoży z tworzyw sztucznych). Następnie opisano najczęstsze przyczyny degradacji archiwalnych materiałów fotograficznych oraz podstawowe procesy, dzięki którym można pozytywnie wpłynąć na „długość życia” zbiorów fotograficznych (w tym przechowywanie obiektów w parametrach obniżonej temperatury i wilgotności względnej powietrza).

Opracowanie kończy opis prewencyjnych działań konserwatorskich niezbędnych do utrzymania zbiorów w dobrym stanie zachowania oraz prawidło-

* Anna Seweryn - mgr konserwacji i restauracji dzieł sztuki, pracownik Archiwum Narodowego w Krakowie

e-mail: aseweryn@ank.gov.pl

https://orcid.org/0000-0003-2351-279X 
wego obchodzenia się z fotografiami podczas prowadzania procesu digitalizacji zbiorów.

Słowa kluczowe: archiwum, fotografia, identyfikacja, konserwacja, negatyw, odbitka, zabezpieczanie

\section{Wstęp}

Fotografie archiwalne to obiekty, które można postrzegać wielowymiarowo. Są one dokumentami, nośnikami realistycznie zapisanego obrazu, często podłożem do ręcznie naniesionych adnotacji lub dopełnieniem zachowanych informacji archiwalnych. Na fotografie można jednak popatrzeć szerzej. Każdy obiekt wytworzony $\mathrm{w}$ technikach fotograficznych to przejaw skomplikowanej technologii i historyczne świadectwo wiedzy i możliwości wytwarzania materiałów archiwalnych w danych czasach. Prawidłowo rozpoznana technika fotograficzna może pomóc przy procesie datowania obiektu, jest także niezbędna na etapie analizy zniszczeń czy planowanego długoterminowego zabezpieczenia i konserwacji fotografii. Historyczne techniki fotograficzne powoli odchodzą w zapomnienie, a ich miejsce zajmują wytwarzane współcześnie obrazy cyfrowe lub cyfrowe reprodukcje materiałów historycznych. Technologia cyfrowa zmienia sposób zapisu obrazu, jak również - poprzez wyeliminowanie tradycyjnej formy nośnika zmienia formę dostępności i kontaktu z obiektami. Dlatego tym bardziej należy docenić materialność historycznych fotografii i zadbać o ich zachowanie dla następnych pokoleń.

Cechami charakterystycznymi obrazu fotograficznego jest jego produkcja $\mathrm{z}$ użyciem substancji światłoczułych ${ }^{1}$ oraz ciągłość tonalna ${ }^{2}$. W archiwach fotografie są dzielone zazwyczaj na dwie grupy - pozytywy (przedstawienia o rzeczywistym rozłożeniu tonów, zwykle w formie odbitek fotograficznych) oraz negatywy (obrazy o odwróconej walorowości, wytworzone na podłożu szklanym lub na podłożu z tworzyw sztucznych). Bardzo rzadko spotyka się w zbiorach fotografie unikatowe, wykonane w bezpośrednich procesach fotograficznych, np. dagerotypy, ambrotypy, autochromy ${ }^{3}$. O ile w przypadku fotografii naświetlonych w procesie bezpośrednim dostęp do niesionej przez obiekty treści jest nieograniczony, o tyle w przypadku negatywów dokładne odczytanie z dokumentu informacji nie jest możliwe bez wykorzystania odpowiedniego sprzętu czy wykonania reproduk-

${ }^{1} \mathrm{~W}$ historii fotografii najczęściej spotykanymi substancjami światłoczułymi są halogenki srebra, czyli jodek, bromek i chlorek srebra; za: T.H. James, The Stability of Silver Filaments, w: Issues in the Conservation of Photographs, eds. D. Hess Norris, J.J. Gutierrez, Los Angeles 2010, s. 116.

${ }^{2} \mathrm{~W}$ odróżnieniu od obrazów produkowanych w technikach drukarskich, na których w powiększeniu widoczny jest zbiór wydrukowanych punktów - raster.

${ }^{3} \mathrm{~W}$ procesie bezpośrednim wytwarza się jeden obraz fotograficzny, który po zakończeniu obróbki chemicznej jest odczytywany jako obraz pozytywowy. Ten typ fotografii był kosztowny i nie dawał możliwości wykonywania kopii otrzymanego przedstawienia. Fotografie wytworzone w tym procesie to fotografie unikatowe, niekopiowalne, m.in. dagerotypy - fotografie srebrowe wytworzone na płycie miedzianej, ambrotypy - fotografie wytworzone na podłożu szklanym z obrazem kolodionowo-srebrowym oraz autochromy - pierwsze fotografie barwne na podłożu szklanym. 
cji. Funkcja fotografii może się bezpośrednio przekładać na jej stan zachowania. Odbitki fotograficzne często udostępniane w formie oryginału mogą nosić znamiona częstej ekspozycji na niepoprawne warunki temperaturowo-wilgotnościowe czy światło oraz ślady niewłaściwego użytkowania. Negatywy - jako obiekty o treści trudnej do odczytania bez użycia odpowiedniego sprzętu - często skazywane są na zapomnienie. To właśnie negatywy, szczególnie w dobie szybko rozwijającej się digitalizacji, stają się często „ofiarami” nieprawidłowych zabiegów przygotowujących zbiory do procesu reprografii, np. niepoprawne cięcie negatywów małoobrazkowych na fragmenty, siłowe prostowanie negatywów na podłożach z tworzyw sztucznych pod obciążaniem, umieszczanie obiektów w nieodpowiednim opakowaniu ochronnych działającym na szkodę tych archiwaliów. Należy pamiętać, że fotografie to dokumenty bardzo delikatnie, a powstające zniszczenia zazwyczaj są nieodwracalne. Sposób wytworzenia obrazu bazujący na procesach fotochemicznych bywa niedoskonały, podłoża mogą być kruche czy degradować się w bardzo krótkim czasie, sam obraz potrafi blaknąć czy odspajać się od warstwy nośnika. Opiekunowie zbiorów archiwalnych, powinni postarać się o przeanalizowanie zbioru fotografii, biorąc pod uwagę ich budowę technologiczną i stan zachowania, a następnie na tej podstawie oszacować potrzeby związane z zabezpieczaniem czy przygotowaniem tych specyficznych dokumentów do procesu digitalizacji.

\section{Techniki i technologie}

Do skomasowania wiedzy pozwalającej na utrwalenie przedstawienia rzeczywistości w postaci fotografii doszło w pierwszej połowie XIX wieku. Oficjalne ogłoszenie wynalazku fotografii nastąpiło 19 sierpnia $1839 \mathrm{r}^{4}$, a pierwsza technika fotograficzna od nazwiska swojego twórcy nazwana została dagerotypią. Louis-Jacques Mandé Daguerre 5 przy współpracy z Nicéphore Niepcé ${ }^{6}$ opracował technikę pozwalającą na wykonanie pojedynczego zdjęcia na płytce miedzianej. Pokrywana ona była srebrem metodą nanoszenia płatków lub galwanizacji, a następnie polerowana. Tak przygotowaną powierzchnię uczulano w parach jodu w następstwie tego procesu na powierzchni płyty powstaje światłoczuły jodek srebra. Obraz naświetlany był w aparacie (początkowo naświetlenie trwało od kilku minut do pół godziny) i wywoływany w parach rtęci, wskutek czego powstawał obraz fotograficzny: amalgamat rtęciowo-srebrowy ${ }^{7}$. Od 1840 r. dagerotypy tonowano chlorkiem złota, co wpływało pozytywnie na stabilność obrazu, nadawało mu większy kontrast oraz cieplejszy ton. $Z$ czasem związki jodu zamieniono na bromki i chlorki, które są bardziej czułe na działanie światła - pozwoliło to na skrócenie czasu naświetlenia do kilku sekund. Aby monochromatycznemu przedstawieniu nadać realistyczne barwy, obraz często kolorowano i pokrywano wer-

${ }^{4}$ Z. Harasym, Stare fotografie. Poradnik kolekcjonera, Kraków 2005, s. 24.

${ }^{5}$ Louis Jacques Mandé Daguerre (1787-1851) - francuski artysta, scenograf, wynalazca dioramy.

${ }^{6}$ Joseph Nicéphore Niépce (1765-1833) - francuski fizyk i wynalazca, autor techniki heliografii i pierwszej utrwalonej fotografii.

${ }^{7}$ B. Lavédrine, Photographs of the Past: Proces and Preservation, Los Angeles 2009, s. 27. 
niksami zabezpieczającymi ${ }^{8}$. Dagerotypy w celu ochronienia przed uszkodzeniem opakowane były w szczelną, oszkloną, ozdobną oprawę o formie szkatułki lub passé-partout. Równocześnie z technologią dagerotypii rozwijała się druga metoda wytwarzania zdjęć, tzw. technika negatywowo-pozytywowa, która z czasem ze względu na niższe koszty produkcji i możliwość wytworzenia wielu kopii obrazu zdominowała rynek fotograficzny. Ogłoszona w 1840 r. przez Williama Henrego Foxa Talbota ${ }^{9}$ kalotypia pozwalała na wytworzenie obrazu negatywowego na podłożu papierowym pokrywanym chlorkiem sodu poprzez zanurzenie kartki lub położenie jej na powierzchni roztworu na kilka minut ${ }^{10}$. Po wyschnięciu papier uczulano $\mathrm{w}$ ciemnym pomieszczeniu roztworem azotanu srebra. $\mathrm{W}$ procesie tym obraz powstaje, gdy bezbarwny chlorek srebra zamienia się na cząsteczki srebra metalicznego pod wpływem działania energii, np. światła. Fotografia jest utrwalana w roztworze tiosiarczanu sodu, który usuwa nienaświetlone związki srebra. Gotowy negatyw przykładano do podobnie przygotowanej technologicznie kartki papieru i wystawiano na działanie słońca, co pozwalało na wytworzenie pozytywu - obrazu o odwróconych walorach. $Z$ czasem obydwa sposoby wytwarzania obrazów (bezpośredni i negatywowo-pozytywowy) rozwinęły się i uległy licznym modyfikacjom, których celem było głównie przyspieszenie procesu fotograficznego (naświetlania i obróbki fotochemicznej), obniżenia kosztów oraz uzyskanie bardziej szczegółowego obrazu. Do wytwarzania warstwy obrazu fotograficznego zaczęto stosować różnorodne spoiwa, jak białko jaja kurzego (np. w technice albuminowej) ${ }^{11}$, kolodion ${ }^{12}$ (zarówno do wytwarzania pozytywów bezpośrednich, jak i negatywów) czy żelatyna ${ }^{13}$. Do dużego skoku technologicznego doszło na przełomie XIX i XX wieku dzięki wprowadzeniu do przemysłu fotograficznego transparentnych błon z tworzyw sztucznych: azotanu celulozy, a następnie octanu celulozy ${ }^{14}$. Nośnik ten wyparł ciężkie i kruche podłoże szklane, pozwolił na minimalizację i większą mobilność aparatów fotograficznych, a z czasem na rozbudowę amatorskiego rynku fotograficznego. Do kolejnej wielkiej zmiany

\footnotetext{
${ }^{8}$ W. Mossakowska, Dagerotypy w zbiorach polskich, Wrocław 1989, s. 13.

${ }^{9}$ William Henry Fox Talbot (1800-1877) - angielski chemik, archeolog i matematyk.

${ }^{10}$ Lavédrine, Photographs of the Past, s. 224.

${ }^{11}$ J.M. Reilly, Care and Identification of 19th-Century Photographic Prints, Rochester 2009,
} s. 27.

${ }^{12}$ Kolodion, czyli roztwór nitrocelulozy w alkoholu i eterze wprowadzono do fotografii w $1847 \mathrm{r}$. Technika mokrego kolodionu była bardzo czuła i skracała czas naświetlenia obrazu do kilku sekund. Jej wadą jest praca „na mokro” - płyta musi być wywołana, gdy rozpuszczalniki jeszcze nie wyparowały z kolodionu; za: Reilly, Care and Identification, s. 28.

${ }^{13} \mathrm{~W} 1871 \mathrm{r}$. Richard Leach Maddox zaproponował nowy rodzaj emulsji fotograficznej na bazie żelatyny. Spoiwo zawierało bromek potasu oraz azotan srebra. W 1878 r. Charles Bennett odkrył, że podgrzewanie tej zawiesiny zwiększa jej czułość, zmniejszając czas naświetlania do setnych sekundy. Negatywy żelatynowo-srebrowe, w odróżnieniu od kolodionowych, mogą być wywołane długo po wykonaniu procesu naświetlenia. Żelatyna fotograficzna była szeroko stosowana przy produkcji papierów fotograficznych.

${ }^{14}$ Identification of Film-Base Photographic Materials, „Conserve O Gram”, 1999, nr 14/9, s. 1. 
w świecie fotografii tradycyjnej doszło w latach 30 . XX wieku, gdy zaczęła się upowszechniać fotografia barwna ${ }^{15}$.

\section{Badania archiwalnych materiałów fotograficznych}

Badania materiałów fotograficznych pod kątem trwałości obrazu i podłoża, identyfikacji technik, poznania przyczyn powstałych zniszczeń, jak również wyznaczenia specyfikacji dla opakowań ochronnych oraz określenia warunków przechowywania i eksponowania to tematy sukcesywnie rozwijane od połowy XX wieku. Wiodącymi międzynarodowymi instytutami naukowo-badawczymi w obszarze materiałów fotograficznych są: Image Permanence Institute (IPI), Getty Conservation Institute (GCI), Centre de Recherches sur la Conservation des Documents Graphiques (CRCGD), Canadian Conservation Institute (CCI), Smithsonian Institute, International Center for the Study of the Preservation and Restoration of Cultural Property (ICCROM), American Society of Heating, Refrigerating and Air Conditioning Engineers (ASHRAE). Instytuty opracowują i publikują rekomendacje dotyczące metod postępowania $\mathrm{z}$ materiałami fotograficznymi. Rekomendacje te uwzględniają najnowszy stan wiedzy oraz poziom techniczny aparatury badawczej. Wypracowane wyniki są przekazywane do Komitetów Technicznych Międzynarodowej Organizacji Normalizacyjnej (ISO) i wydawane w postaci norm, tj. dokumentów mających na celu normalizację i standaryzację działań w obszarze postępowania $\mathrm{z}$ różnymi grupami materiałów fotograficznych. Normy nie są dokumentami prawnie obowiązującymi. Ich stosowanie jest dobrowolne, ale podmioty odpowiedzialne za kreowanie polityki ochrony obiektów zabytkowych powinny postępować zgodnie z wytyczonymi normami w celu zachowania narodowego dziedzictwa kulturowego dla przyszłych pokoleń. Przykładami najważniejszych norm opracowanych dla różnych rodzajów materiałów fotograficznych są: ISO 18920:2011 Imaging Materials - Reflection Prints - Storage Practices [Nośniki obrazu - Przechowywanie obiektów wytworzonych w różnych procesach powielania obrazu], ISO 18934:2011 Imaging Materials - Multiple Media Archives - Storage Environment [Nośniki obrazu Różne rodzaje nośników danych - Warunki przechowywania], ISO 18916:2007 Imaging Materials - Processed Imaging Materials - Photographic Activity Test for Enclosure Materials [Nośniki obrazu - Procedury i metody testowania materiałów używanych do produkcji opakowań ochronnych do długoterminowego przechowywania materiałów fotograficznych, atest PAT].

Dostęp do zaawansowanych badań naukowych oraz do nowoczesnych technologii stosowanych w przechowywaniu materiałów fotograficznych stwarzają nowe możliwości do zarządzania zbiorami fotograficznymi. Wśród międzynarodowych specjalistów opracowujących i publikujących w zakresie fotografii archiwalnej, na których dorobku bazują kolejne pokolenia konserwatorów fotografii, wymienić można James'a M. Reillego, Bertrand'a Lavédrine’a i Sylvie Péni-

${ }^{15}$ Do masowej produkcji i rozpowszechniania materiałów fotograficznych barwnych doszło po II wojnie światowej za sprawą systemów negatywowo-pozytywowych firmy Agfa (1939) i Kodak (1942); za: Lavédrine, Photographs of the Past, s. 212. 
chon $^{16}$. Do najlepiej opracowanych zagadnień z dziedziny konserwacji fotografii zalicza się metodykę identyfikacji technik i technologii fotograficznych ${ }^{17}$, degradację i zabezpieczanie podłoży z tworzyw sztucznych ${ }^{18}$, wytyczne dotyczące wyboru opakowań ochronnych oraz podstawowe procesy konserwatorskie.

Za punkt zwrotny w postępowaniu ze zbiorami materiałów fotograficznych w Polsce można uznać pierwszą ogólnopolską konferencję poświęconą zabezpieczaniu, digitalizacji i udostępnianiu materiałów fotograficznych w zbiorach archiwów, bibliotek i muzeów. Konferencja została zorganizowania w 2002r. z inicjatywy Archiwum Państwowego w Krakowie - członka Programu ds. Ochrony i Udostępniania Europejskich Zbiorów Fotograficznych SEPIA i ówczesnej kierownik pracowni konserwacji materiałów archiwalnych Pani Anny Michaś. W konferencji wzięli udział przedstawiciele archiwów, bibliotek, muzeów, nauczyciele akademiccy, właściciele galerii, kolekcjonerzy oraz studenci. Wykładowcami byli międzynarodowi eksperci w dziedzinie identyfikacji, zabezpieczania i konserwacji materiałów fotograficznych m.in. Clara von Waldthausen, wykładowca w pracowni konserwacji fotografii na Uniwersytecie w Amsterdamie. Konferencja ta zapoczątkowała wzrost zainteresowania polskimi zbiorami fotografii, zwróciła uwagę na potrzebę zmiany polityki postępowania ze zbiorami oraz odpowiedniego wykształcenia kadry. Kolejne lata przyniosły wprowadzenie zajęć z podstaw identyfikacji i zabezpieczania archiwalnych materiałów fotograficznych na wydziałach kształcących w Polsce konserwatorów dzieł sztuki: Wydziale Konserwacji i Restauracji Dzieł Sztuki Akademii Sztuk Pięknych w Krakowie, Wydziale Konserwacji i Restauracji Dzieł Sztuki Akademii Sztuk Pięknych w Warszawie oraz w Katedrze Konserwacji-Restauracji Papieru i Skóry Uniwersytetu Mikołaja Kopernika w Toruniu. W 2018 r. katedra ta zorganizowała międzynarodową konferencję dedykowaną konserwacji fotografii Czarno-biaty obraz świata. Problemy ochrony dawnych fotografii, na której swój dorobek z zakresu konserwacji, badania i zabezpieczania materiałów fotograficznych zaprezentowało wielu specjalistów z uczelni i instytucji w Polsce ${ }^{19}$.

\section{Identyfikacja technologiczna zbiorów}

W polskich instytucjach zajmujących się gromadzeniem i przechowywaniem obiektów zabytkowych materiały fotograficzne stanowią grupę obiektów stosunkowo „młodych”. Pracując z fotografią, należy zdawać sobie sprawę z rozbudowanej struktury tych obiektów, która nie jest widoczna nieuzbrojonym okiem. Ar-

\footnotetext{
${ }^{16}$ James M. Reilly - emerytowany profesor w Rochester Institute of Technology, były dyrektor Image Permanence Institute w Rochester; Bertrand Lavédrine - były dyrektor Centre de Recherches sur la Conservation des Documents Graphiques w Paryżu; Sylvie Pénichon - konserwatorka fotografii w Art Institute of Chicago, autorka książki: Twentieth-Century Color Photographs, Identification and Care, Los Angeles 2003.

${ }^{17}$ J.M. Reilly, Care and Identification of 19th-Century Photographic Prints, Rochester 2009.

${ }^{18}$ J.M. Reilly, IPI Storage Guide for Acetate Film, Rochester 1996.

${ }^{19} \mathrm{~W}$ druku ukazały się materiały pokonferencyjne: Czarno-biaty obraz świata. Problemy ochrony dawnych fotografii/Black and White Image of the World. Issues in the Conservation of Photographs, red. E. Jabłońska, T. Kozielec, Torun 2018.
} 
chiwalne materiały fotograficzne to obiekty o wielowarstwowej budowie. Przez ponad 180 lat istnienia wynalazku fotografii sposób wykonywania zdjęć, wykorzystywane do tego celu materiały zmieniały się, pozwalając na coraz bardziej efektywne, łatwiejsze i doskonalsze uwiecznianie rzeczywistości. Wśród podłoży stosowanych w fotografii wyróżnić można papier, szkło, tworzywa sztuczne, ale także tkaninę i porcelanę. Znajdująca się na powierzchni podłoża warstwa obrazu zazwyczaj składa się z dwóch elementów: cząsteczek budujących sam obraz oraz transparentnego spoiwa, w którym cząstki te są zawieszone. W fotografii najczęściej spoiwami są substancje pochodzenia zwierzęcego: żelatyna oraz białko jaja kurzego, a obraz budowany jest z cząsteczek srebra, żelaza, barwników lub pigmentów. Każda z indywidualnych składowych fotografii inaczej degraduje w czasie i jest bardziej lub mniej wrażliwa na szkodliwe czynniki, takie jak zbyt wysoka temperatura $\mathrm{w}$ miejscu przechowywania zbiorów, wysoka wilgotność względna powietrza czy niewłaściwe obchodzenie się z obiektem.

Rozpoznanie technologiczne zbiorów fotograficznych oraz oszacowanie ich stanu zachowania pozwala określić priorytety w zarządzaniu kolekcją fotograficzną. Identyfikacja techniki wykonania odbitek fotograficznych wymaga skupienia i wcześniejszego zapoznania się z najistotniejszymi cechami danej techniki. Fotografię najpierw należy obejrzeć w świetle padającym i odbitym, próbując przeanalizować barwę oraz powierzchnię obrazu fotograficznego. Następnie lico obiektu powinno się zbadać w powiększeniu, za pomocą mikroskopu lub lupy jubilerskiej. Proces ten pozwoli na zaobserwowanie wielowarstwowej budowy fotografii, od papierowego podłoża, warstwy barytowej aż po sam obraz fotograficzny ${ }^{20}$. W polskich archiwach najpopularniejszymi fotografiami są odbitki żelatynowo-srebro$w^{21}$, ale wśród starszych zbiorów można spotkać także liczne odbitki albuminowe i kolodionowe ${ }^{22}$. Podczas przeglądania zbiorów bardzo istotnym jest wydzielenie fotografii barwnych, które są bardziej wrażliwe na działanie czynników zewnętrznych niż np. fotografie srebrowe ${ }^{23}$ i wymagają specjalnych warunków przecho-

${ }^{20}$ Odbitki fotograficzne dzieli się na trzy podstawowe grupy: odbitki jednowarstwowe, np. wykonane w technice papieru solnego czy cyjanotypii (w powiększeniu widoczny będzie obraz osadzony bezpośrednio na włóknach papieru), odbitki dwuwarstwowe, np. w technice albuminowej (obraz osadzony jest w spoiwie na powierzchni papierowego podłoża) oraz odbitki trójwarstwowe, np. żelatynowo-srebrowe lub kolodionowe (między papierowym podłożem a warstwą obrazu znajduje się warstwa barytowa - włókna papieru nie są widoczne).

${ }^{21}$ Odbitki żelatynowo-srebrowe produkowane są od 1880 r. Mają one różnorodną tonację oraz powierzchnię - od bardzo błyszczącej po matową. Wyróżnia je także trójwarstwowa budowa (podłoże papierowe, warstwa barytowa, warstwa obrazu); za: Lavédrine, Photographs of the Past, s. 138.

${ }^{22}$ Odbitki albuminowe (1850-1900) charakteryzują żółte partie świateł, mikrospękania w warstwie spoiwa oraz zanikanie detalu obrazu. Fotografie te mają dwie warstwy - papierowe podłoże oraz warstwę obrazu. Odbitki kolodionowe błyszczące charakteryzuje m.in. gładka i błyszcząca powierzchnia oraz sino-szare partie świateł.

${ }^{23}$ Fotografie srebrowe przede wszystkim powinny mieć otoczenie czyste chemicznie, tj. atestowane i stabilne opakowanie ochronne oraz czyste chemicznie powietrze w miejscu przechowywania zbiorów; za: K.B. Hendriks, On the Mechanism of Image Silver Degradation, w: Issues in the Conservation, s. 234. 
wywania ${ }^{24}$. Innymi materiałami, które powinno się zidentyfikować i poddać specjalistycznemu zabezpieczeniu są transparentne podłoża sztuczne, będące nośnikiem obrazu negatywowego, mikrofilmu lub barwnego slajdu. Wśród plastików w archiwach fotograficznych znajdują się azotan celulozy, octan celulozy oraz poliester ${ }^{25}$. Pierwszym rodzajem podłoża wprowadzonym na rynek fotograficzny i filmowy w 1899 r. był azotan celulozy (celuloid) ${ }^{26}$. Podłoże to jest bardzo niestabilne, łatwopalne, szybko i dynamicznie degraduje, wydzielając jednocześnie szkodliwe dla innych archiwaliów oraz ludzi substancje lotne ${ }^{27}$, w ekstremalnych sytuacjach może ulegać samozapłonowi, a w końcowej fazie rozkładu zamienia się w bursztynowy pył. W latach 20 . XX wieku wprowadzono do użytku podłoża na bazie octanu celulozy, który nie niesie ze sobą tak wysokiego ryzyka pożaru, jednak z czasem także ulega szybkim i nieodwracalnym zniszczeniom zwanym od wydzielanego wtedy zapachu syndromem octowym ${ }^{28}$. Za najbardziej stabilne podłoże transparentne $\mathrm{w}$ fotografii uważa się poliester wprowadzony do fotografii w latach 50. XX wieku. Proces identyfikacji podłoża sztucznego należy rozpocząć od odszukania informacji naniesionej podczas produkcji na sam nośnik. Kody lub pełne wyrazy występują w miejscu pozbawionym obrazu, na marginesie negatywu lub pomiędzy perforacją. Filmy z napisem nitrate oznaczają celuloid, safety film lub $S$ - film wytworzony na bazie octanu celulozy, a z napisem estar - poliester. Niestety nie wszystkie obiekty mają dokładną informację o składzie chemicznym tworzywa. W przypadku braku danych o rodzaju zastosowanego plastiku, rodzaj podłoża można zidentyfikować, analizując jego barwę i stan zachowania, w tym biorąc pod uwagę charakterystyczne objawy starzenia się poszczególnych błon. Azotan celulozy ma tendencję do degradowania obrazu srebrowego (czerń zyskuje kolor żółty, różowy, zielony), z czasem żółknie i brunatnieje, stając się kruchym, by finalnie zamienić się w pył. Octan celulozy kurczy się, co może powodować powstawanie zmarszczek w partii obrazu fotograficznego. Błona ta ma także często niebieskawe lub szare zabarwienie. Istnieją także chemiczne metody identyfikacji podłoży, jednak wymagają one użycia niebezpiecznych odczynników chemicznych ${ }^{29}$. Materiały na bazie azotanu i octanu celulozy powinny zostać wydzielone i odpowiednio zabezpieczone, m.in. poprzez umieszczenie

${ }^{24}$ Jednym $\mathrm{z}$ najtrudniejszych zagadnień związanych $\mathrm{z}$ fotografią o obrazie wykonanym na bazie barwników są zmiany kolorystyczne w tonacji zdjęcia oraz blaknięcie. Problemy te związane się z małą stabilnością użytych do produkcji obrazu substancji oraz szybką degradacją barwników szczególnie w przypadku narażenia zbiorów na działanie światła czy też podwyższonej temperatury i wilgotności względnej powietrza; za: R.J. Tuite, Image Stability in Color Photography, w: Issues in the Conservation, s. 475.

${ }^{25}$ C.M. Fischer, A. Robb, Guidelines for Care and Identification of Film-Base Photographic Materials, w: Issues in the Conservation, s. 401.

${ }^{26}$ B. Lavédrine, A Guide to the Preventive Conservation of Photograph Collections, 2009, s. 16.

${ }^{27}$ G. Hill, New Nitrate Film Storage for Library and Archives, „Topics in Photographic Preservation", 2003, nr 10, s. 75 .

${ }^{28}$ Lavédrine, A Guide to the Preventive Conservation, s. 19.

${ }^{29}$ A. Seweryn, Identyfikacja, degradacja i zabezpieczanie materiałów fotograficznych wytworzonych na podtożach z estrów celulozy, „Notes Konserwatorski”, 2019 nr 21, s. 235. 
w pomieszczeniu o znacząco obniżonych parametrach temperaturowo-wilgotnościowych. Fotografie wytworzone na tworzywach ulegających szybkiej destrukcji fizycznej powinny być typowane w pierwszej kolejności do procesu digitalizacji.

\section{Identyfikacja czynników szkodliwych i degradacja}

Patrząc na fotografię, należy pamiętać, że obraz fotograficzny powstaje przy zastosowaniu odczynników chemicznych w wyniku działania światła na materiał światłoczuły. Wywołany i utrwalony obraz jest cały czas reaktywny, czyli zdolny do reagowania ze związkami chemicznymi z jego bezpośredniego otoczenia $^{30}$. Skomplikowana natura fotografii sprawia, że substancje tworzące obraz oraz związki obecne w podłożu nieustannie na siebie oddziałują, a także reagują ze związkami chemicznymi obecnymi w otaczającym je środowisku. Tak jak w przypadku innych materiałów archiwalnych fotografie są wrażliwe na niewłaściwą temperaturę i wilgotność względną powietrza ${ }^{31}$, światło ${ }^{32}$, zagrożenia biologiczne $^{33}$, zanieczyszczenia chemiczne. Plan zabezpieczenia kolekcji powinno się rozpocząć od zidentyfikowania najbardziej szkodliwych czynników znajdujących się w miejscu przechowywania i użytkowania zbiorów oraz opracowania planu ich eliminacji. Złe parametry temperaturowo-wilgotnościowe prowadzą do przyspieszenia reakcji chemicznych powodujących starzenie się materii organicznej. Podłoża fotografii mogą się kurczyć, pękać i deformować, warstwa obrazu może się odspoić od podłoża, a także ulegać przebarwieniu, kruszyć się i łuszczyć. Bardzo niebezpieczne dla zbiorów fotograficznych są duże fluktuacje dobowe parametrów, szczególnie dynamiczny wzrost wilgotności względnej powietrza, który może doprowadzić do infekcji mikrobiologicznej zbiorów. Ze względu na dużą wrażliwość materiałów fotograficznych na wodę powinny być one także w specjalny sposób traktowane na wypadek wystąpienia zalania zbiorów. Najbardziej

${ }^{30}$ Do szczególnie nietrwałych zaliczyć możemy fotografie wykonane w pierwszych procesach fotograficznych, gdy procesy chemiczne nie były jeszcze dokładnie rozpoznane, a obróbka fotochemiczna mogła być wykonana niepoprawnie. Do szczególnie zagrożonych obiektów należą także fotografie na podłożu papierowym, które długo kumuluje chemię i wilgoć podczas procesu obróbki chemicznej; za: E. Ostroff, Preservation of Photographs, w: Issues in the Conservation, s. 11.

${ }^{31}$ Wilgotność względna powietrza (RH) to wyrażony w procentach stosunek ilości obecnej w powietrzu pary wodnej, która nasyciłaby powietrze w określonej temperaturze i ciśnieniu.

${ }^{32}$ Światło dzienne i sztuczne prowadzi do degradacji obiektów zabytkowych. Światło jest falą elektromagnetyczną. Fale wszystkich długości: widzialne (400-700 nm), nadfioletowe UV (poniżej $400 \mathrm{~nm}$ ) i podczerwone IR (powyżej $800 \mathrm{~nm}$ ) powodują chemiczny rozkład materii organicznej. Zniszczenia spowodowane przez działanie światła są nieodwracalne i kumulowane w czasie. Reakcje chemiczne trwają nadal, nawet gdy źródło światła zostało usunięte, a obiekt umieszczony w zaciemnionym magazynie.

${ }^{33}$ Grzyby pleśniowe przystosowują się do zmiennych warunków środowiskowych. Ich zarodniki mają zdolność przetrwania w niesprzyjających warunkach środowiskowych. Przechodząc w postać przetrwalnikową, są w stanie egzystować przez wiele lat, w sprzyjających warunkach uaktywniają się ze wzmożoną intensywnością. Zagrzybione obiekty wydzielają mykotoksyny MVOC (ang. microbial volatile organic compounds), które wywołują infekcje grzybicze, alergiczne, zatrucia pokarmowe, osłabiają układ immunologiczny, a w skrajnych przypadkach mają działanie mutagenne i rakotwórcze. 
powszechne materiały fotograficzne zbudowane na bazie żelatyny fotograficznej pod wpływem zawilgocenia stają się lepkie, co może doprowadzić do sklejenia się obiektów ze sobą lub opakowaniem ochronnym. Sama żelatyna fotograficzna bardzo szybko się rozpuszcza, a zniszczonego w ten sposób obrazu nie można już odtworzyć.

Dla obrazu fotograficznego czynnikiem silnie degradującym są lotne substancje chemiczne. Zanieczyszczenia gazowe dzielą się na zanieczyszczenia zewnętrzne, pochodzące ze źródeł przemysłowych i motoryzacyjnych, oraz zanieczyszczenia wewnętrzne, wydzielane przez farby, lakiery, kleje czy meble wykonane z materiałów drewnopochodnych. Substancje te mogą łączyć się ze składowymi obrazu fotograficznego i doprowadzać do jego przebarwień, utraty kontrastowości czy zanikania. Dla obiektów szkodliwe są także zanieczyszczenia pyłowe, czyli cząstki zanieczyszczeń stałych przenoszone drogą powietrzną, takie jak sadza, kurzu i pyłu. Cząstki te są przyczyną uszkodzeń chemicznych i mechanicznych obiektów, a znajdujące się w zanieczyszczeniach zarodniki grzybów mogą powodować infekcje mikrobiologicznej. Innym czynnikiem niszczącym zbiory fotograficzne jest niewłaściwe obchodzenie się z obiektami. Fotografie często są przeglądane w pospiechu, bez wyłożenia blatu roboczego materiałem ochronnym, rękami bez rękawiczek. Ponadto bywają umieszczane w nieodpowiednich opakowaniach ochronnych, w niewłaściwy sposób montowane w ramach ekspozycyjnych, narażane na działanie światła, poddawane niewłaściwym, siłowym procesom prostowania pod obciążeniem.

\section{Zabezpieczenie fotografii}

Zabezpieczanie fotografii, tak jak w przypadku wszelkich materiałów archiwalnych, to proces wieloetapowy, na który składają się odpowiednie opakowania ochronne, meble, przestrzenie magazynowe oraz panujący w magazynach klimat. Rekomendacje konserwatorskie precyzują, że materiały fotograficzne powinny być przechowywane w wydzielonych magazynach zbiorów, w stałej i odpowiedniej temperaturze oraz wilgotności względnej powietrza, dostosowanych do określonego rodzaju techniki fotograficznej. Warunki środowiskowe w magazynach zbiorów fotograficznych należy monitorować i rejestrować, a rejestry - analizować systematycznie .

Meble do przechowywania fotografii powinny być wykonane $\mathrm{z}$ aluminium anodowego, stali nierdzewnej lub pokrytej lakierem piecowym ${ }^{34}$. Metal, drewno lub materiały drewnopodobne emitują związki lotne, np. toksyczny formaldehyd lub jony metali, które reagują z cząsteczkami srebra budującymi obraz fotograficzny i bezpośrednio wpływają na pogorszenie się jego stanu zachowania. Dodatkowo materiały porowate kondensują kurz i mogą stać się siedliskiem owadów. Meble z fotografiami nie powinny być przysunięte bezpośrednio do ścian magazynu. Wskazane jest by miały perforację, co zapewni odpowiedni obieg powie-

${ }^{34}$ Naczelna Dyrekcja Archiwów Państwowych, Zasady postępowania z materiałami archiwalnymi. Ochrona zasobu archiwalnego, wybór i oprac. M. Borowski. A. Czajka, A. Michaś, Warszawa 2011, s. 63. 
trza wokół przechowywanych zbiorów. W przypadku zbiorów fotograficznych o szczególnych wymaganiach do mebli służących do przechowywania zbiorów zaliczyć można także chłodziarki, zamrażarki oraz szafy ognioodporne. Powietrze w magazynie zbiorów powinno być filtrowane, by uwolnić je od atmosferycznych zanieczyszczeń gazowych i pyłowych. Dostęp do magazynu światła dziennego musi być zablokowany, a urządzenia generujące światło sztuczne powinny mieć filtry UV i IR lub wytwarzać minimalne ilości szkodliwego dla fotografii promieniowania elektromagnetycznego.

Materiały fotograficzne należy przechowywać w atestowanych opakowaniach ochronnych mających atest PAT (ISO Standard 18916:2007) ${ }^{35}$. Zarówno opakowania indywidualne, jak i zbiorcze muszą być dostosowane do wymiaru i ciężaru obiektów. Opakowania historyczne oraz opakowania bez atestu mogą zawierać związki agresywne, takie jak siarczan glinu, ałun glinowo-potasowy oraz barwniki i wybielacze, które wywołują chemiczny rozkład obrazu i podłoża. Do przechowywania fotografii zalecane są opakowania wykonane z papieru lub opakowania hybrydowe (papier łączony z poliestrem). Papier jest buforem dla obiektu, zapewnia jego wentylację i może neutralizować zanieczyszczenia powietrza. Poliester często używany do wytwarzania koszulek na fotografię jest przeźroczysty, odporny na przedarcia, stabilny chemicznie, ale także elektrostatyczny, może się jednak przykleić do warstwy obrazu podczas zawilgocenia i ,zatrzymywać” szkodliwe substancje bezpośrednio przy fotografii, wewnątrz opakowania. Można go użyć jako składową opakowania ochronnego w przypadku, gdy fotografia jest często udostępniana i nie ma wersji cyfrowej. Atest PAT powinien być jedynie podstawą przy wyborze odpowiednich opakowań ochronnych dla zbiorów, a nie jedynym czynnikiem decydującym o wyborze danej koszulki ochronnej czy pudła zbiorczego. Równie istotnymi parametrami jest grubość zastosowanego papieru czy tektury, użyte kleje i konstrukcja opakowania.

Nie ma jednej właściwej wartości temperatury i wilgotności względnej powietrza optymalnej w miejscu przechowywania zbiorów dla wszystkich typów materiałów fotograficznych. Parametry należy dostosować do konkretnego rodzaju archiwaliów, uwzględniając skład obrazu i rodzaj podłoża fotograficznego. Wskaźniki te powinny być przede wszystkim stabilne i w skali doby ulegać jedynie nieznacznym fluktuacjom. Obniżenie temperatury oraz wilgotności względnej powietrza w magazynie przechowywania zbiorów spowolni szkodliwe rekcje chemiczne odpowiedzialne za degradację materiałów fotograficznych. Fotografia srebrowa wytworzona na podłożu papierowy czy szklanym może być przechowywana $\mathrm{w}$ temperaturze pokojowej $\left(18-21^{\circ} \mathrm{C}\right)$. Dla mieszanej kolekcji fotografii zalecana jest wilgotność względna powietrza w granicach 30-50\% $\mathrm{RH}^{36}$. Fotografie

${ }^{35}$ Test PAT określa interakcję między obiektem a opakowaniem ochronnym wykonanym z papieru, tektury lub tworzywa sztucznego, ale może być także użyty do badania innych materiałów np.: kleju, tuszu czy farby. Zaliczenie testu przez dany materiał jest dowodem na jego neutralność w stosunku do przechowywanej w nim fotografii, a jego bezpośrednia obecność przy obiekcie nie powinna powodować degradacji obrazu, blaknięcia barwników, migracji spoiw czy plastyfikatorów.

${ }^{36}$ Reilly, Care and Identification, s. 83 
na bazie niestabilnych składowych, np. podłoża z octanu celulozy czy fotografie barwne, powinny być przechowywane w pomieszczeniach ze znacząco obniżoną temperaturą $\mathrm{i}$ wilgotnością względną powietrza ${ }^{37}$. Wskazana jest tu temperatura zbliżona do $0^{\circ}$, a nawet temperatura mrożenia (niektóre zachodnie instytucja przechowują zbiory w temperaturze $-18^{\circ}$ ). Do celów przechowywania tak specjalistycznych zbiorów adaptuje się odpowiednie chłodnie przemysłowe lub lodówki. W niskotemperaturowym przechowywaniu zbiorów konieczna jest kontrola wilgoci, w specjalistycznych chłodniach wykonywana zazwyczaj automatycznie lub poprzez zabezpieczenie danej jednostki odpowiednim opakowaniem ochronnym w przypadku wykorzystania lodówek. Realizacja zadania związanego z przeniesieniem kolekcji fotograficznej do magazynu o obniżonej temperaturze powinna być konsultowana z konserwatorem fotografii. Decyzja o niskotemperaturowym przechowywaniu materiałów fotograficznych, prócz zakupu odpowiedniego sprzętu i materiałów, selekcji i przygotowania zbiorów, wymaga także stworzenia osobnych procedur udostępniania akt i przygotowania się na wypadek dodatkowych zagrożeń, w tym zawilgocenia obiektów spowodowanego awarią urządzeń chłodzących czy wystąpieniem katastrofy ${ }^{38}$.

\section{Konserwacja i przygotowanie do digitalizacji}

Planując proces konserwacji zbiorów fotograficznych należy przede wszystkim podjąć współpracę z konserwatorem-specjalistą w tej wąskiej dziedzinie, których w Polsce jest wciąż niewielu. Przekazanie fotografii osobie niekompetentnej może skutkować wykonaniem na obiektach szkodliwych zabiegów, dedykowanych przykładowo dokumentom papierowym, jak np. odkwaszanie. Instytucje zazwyczaj nawiązują współpracę z konserwatorem w przypadku ostateczności, gdy dojdzie do katastrofy zagrażającej zbiorom, do masowej infekcji mikrobiologicznej lub stan fotografii nie pozwala uzyskać z nich kopii cyfrowej podczas planowanego projektu digitalizacji zbiorów. Każde archiwum i każdy rodzaj dokumentów powinien przejść przegląd konserwatorski, który pozwoliłby na profesjonalne określenie priorytetów w zabezpieczaniu i zarządzaniu daną kolekcją.

Proste procesy z zakresu konserwacji prewencyjnej można wykonywać samodzielnie podczas prac porządkowych prowadzonych przy materiałach archiwalnych. Do prac takich zalicza się powierzchniowe oczyszczanie fotografii z zabrudzeń niezbędne, np. przed przeniesieniem dokumentu do nowego opakowania ochronnego. Proces taki należy wykonywać, aby nie porysować delikatnej po-

${ }^{37} \mathrm{H}$. Wilhelm, The Permanence and Care of Color Photographs: Traditional and Digital Color Prints, Color Negatives, Slides and Motion Pictures, Grinnell 1993, s. 301

${ }^{38} \mathrm{Każda} \mathrm{instytucja} \mathrm{przechowująca} \mathrm{zbiory} \mathrm{powinna} \mathrm{mieć} \mathrm{opracowany} \mathrm{plan} \mathrm{na} \mathrm{wypadek} \mathrm{wystą-}$ pienia katastrofy. Pożar czy zalanie materiałów archiwalnych niestety się zdarzają i w przypadku zaistnienia sytuacji kryzysowej instytucja powinna dysponować m.in. listą wytypowanych najcenniejszych obiektów, zespołem osób odpowiedzialnych za reagowanie na wystąpienie katastrofy, magazynem materiałów ratunkowych. Podstawowe informacje o sposobach przygotowywania się na wypadek wystąpienia katastrofy można uzyskać w publikacji: A. Czajka, Zasady postępowania z materiatami archiwalnymi: ochrona zasobu archiwalnego. Przygotowanie na wypadek katastrofy, Warszawa 2006. 
wierzchni obrazu fotograficznego. Do oczyszczania używa się pędzli z miękkim włosiem, mikrofibry, czyścików z nanocząsteczkami srebra. Bardziej skomplikowane procesy należy wykonywać po przeszkoleniu przez konserwatora. W archiwach, szczególnie podczas prowadzenia prac reprograficznych, często wykonuje się prace związane z oczyszczaniem chemicznym fotografii, głównie negatywów żelatynowo-srebrowych wytworzonych na szklanym podłożu. Prace te należy wykonywać na półsucho, jedynie na powierzchni szklanego podłoża obiektu, po wcześniejszym sprawdzeniu czy na powierzchni szyby szklanej nie znajduje się retusz fotograficzny. Przy oczyszczaniu obowiązkowo stosuje się wodę destylowaną oraz rozpuszczalniki czyste chemicznie. Bardziej skomplikowane procesy konserwatorskie należy pozostawić specjalistom, np. chemiczne oczyszczanie lica odbitek fotograficznych, sklejanie rozdartych odbitek fotograficznych, prostowanie negatywów wytworzonych na błonach z tworzyw sztucznych, konserwacja obiektów nietypowych lub o złożonej budowie technologicznej. Fotografie skażone mikrobiologicznie zazwyczaj poddawane są procesowi minimalizacji ilości pleśni, tzn. pleśń jest usuwana ręcznie w sposób chemiczny i mechaniczny, a następnie fotografiom zapewniane są właściwe warunki przechowywania niwelujące ryzyko odnowienia się infekcji mikrobiologicznej ${ }^{39}$. Odkażanie tlenkiem etylenu - stosowane w dezynfekcji materiałów na podłożu papierowym - nie jest wskazane w przypadku fotografii ze względu na delikatny obraz srebrowy i możliwość jego zniszczenia w następstwie kontaktu z wymieniona substancją. Poddanie fotografii procesowi fumigacji ma uzasadnienie w przypadku wykrycia w badaniu mikrobiologicznym mikroorganizmów niebezpiecznych dla życia i zdrowia człowieka.

Digitalizacja fotografii powinna uwzględniać dostosowanie sprzętów do danego rodzaju materiału fotograficznego. Coraz częściej skanery wypierane są przez bezpieczniejszą dla materiałów fotograficznych reprografię za pomocą aparatu fotograficznego. W przypadku wytwarzania kopii cyfrowych za pomocą skanerów należy pamiętać, że urządzenia te nagrzewają się, co ma negatywny wpływ na fotografię, a skutki działania temperatury na materiał archiwalny mogą być widoczne pod postacią powstania deformacji bądź skurczu podłoża obiektu. W procesie digitalizacji okres narażenia fotografii na działanie podwyższonej temperatury czy nadmiernej ilości promieniowania elektromagnetycznego powinien być ograniczony do minimum. Podczas przenoszenia materiałów fotograficznych pomiędzy magazynem archiwalnym a pomieszczeniem o odmiennych warunkach klimatycznych, obiekty należy poddać aklimatyzacji, a czas oraz warunki kondycjonowania - dostosować do różnicy parametrów temperatury i wilgotności względnej powietrza pomiędzy obu pomieszczeniami. W pomieszczeniu wykonywania reprografii muszą panować stabilne warunki temperaturowo-wilgotnościowe. Fotografię po podaniu jej procesowi digitalizacji powinno się niezwłocznie umieścić w pierwotnym opakowaniu ochronnym i przenieść do magazynu przechowywania zbiorów.

${ }^{39}$ G.T. Eaton, Conservation of Photographs, Rochester 1985, s. 137. 


\section{Zakończenie}

Planując długoterminowy program opieki nad zbiorami fotograficznymi, należy ustalić priorytety, które zależne są od wielkości kolekcji, techniki wykonania zgromadzonych fotografii, możliwości kadrowych, lokalowych oraz finansowych instytucji. Działania te wymagają skorelowani prac przy inwentaryzacji i identyfikacji zbiorów, planowaniu oczyszczania i przepakowania fotografii, przygotowania odpowiednich pomieszczeń do przechowywania zbiorów oraz udostępniania oryginałów. Przedsięwzięcia prowadzone na materiałach archiwalnych powinno się połączyć z systematyczną digitalizacją zbiorów pozwalającą na szerokie udostępnianie kopii cyfrowych celem ochrony historycznych nośników.

\section{REFERENCES / BIBLIOGRAFIA}

Czajka Anna, Zasady postępowania z materiatami archiwalnymi: ochrona zasobu archiwalnego. Przygotowanie na wypadek katastrofy, Warszawa 2006.

Eaton George T., Conservation of Photographs, Rochester 1985.

Fischer Monique C., Robb Andrew, Guidelines for Care and Identification of Film-Base Photographic Materials, w: Issues in the Conservation of Photographs, eds. D. Hess Norris, J.J. Gutierrez, Los Angeles 2010, s. 696-698.

Harasym Zenon, Stare fotografie. Poradnik kolekcjonera, Warszawa 2005.

Hendriks Klaus B., On the Mechanism of Image Silver Degradation, w: Issues in the Conservation of Photographs, eds. D. Hess Norris, J.J. Gutierrez, Los Angeles 2010, s. 227-235.

Hill Greg, New Nitrate Film Storage for Library and Archives, „Topics in Photographic Preservation", (2003) nr 10, s. 74-85.

Identification of Film-Base Photographic Materials, „Conserve O Gram”, (1999) nr 14/9, s. 1-4.

James Thomas H., The Stability of Silver Filaments, w: Issues in the Conservation of Photographs, eds. D. Hess Norris, J.J. Gutierrez, Los Angeles 2010, s. 116-138.

Lavédrine Bertrand, A Guide to the Preventive Conservation of Photograph Collections, Los Angeles, 2009.

Lavédrine Bertrand, Photographs of the Past: Proces and Preservation, Los Angeles 2009.

Mossakowska Wanda, Dagerotypy w zbiorach polskich, Wrocław 1989.

Naczelna Dyrekcja Archiwów Państwowych, Zasady postępowania z materiatami archiwalnymi. Ochrona zasobu archiwalnego, wybór i oprac. M. Borowski. A. Czajka, A. Michaś, Warszawa 2011.

Ostroff Eugene, Preservation of Photographs, w: Issues in the Conservation of Photographs, eds. D. Hess Norris, J.J. Gutierrez, Los Angeles 2010, s. 8-20.

Pénichon Sylvie, Twentieth-Century Color Photographs, Identification and Care, Los Angeles 2003.

Reilly James M., IPI Storage Guide for Acetate Film, Rochester 1996.

Reilly James M., Care and Identification of 19th-Century Photographic Prints, Rochester 2009

Seweryn Anna, Identyfikacja, degradacja i zabezpieczanie materiatów fotograficznych wytworzonych na podtożach z estrów celulozy, „Notes Konserwatorski”, 2019, nr 21, s. $225-245$. 
Tuite Robert J., Image Stability in Color Photography, w: Issues in the Conservation of Photographs, eds. D. Hess Norris, J.J. Gutierrez, Los Angeles 2010, s. 471-489.

Wilhelm Henry, Brower Carol, The Permanence and Care of Color Photographs: Traditional and Digital Color Prints, Color Negatives, Slides and Motion Pictures, Grinnell 1993.

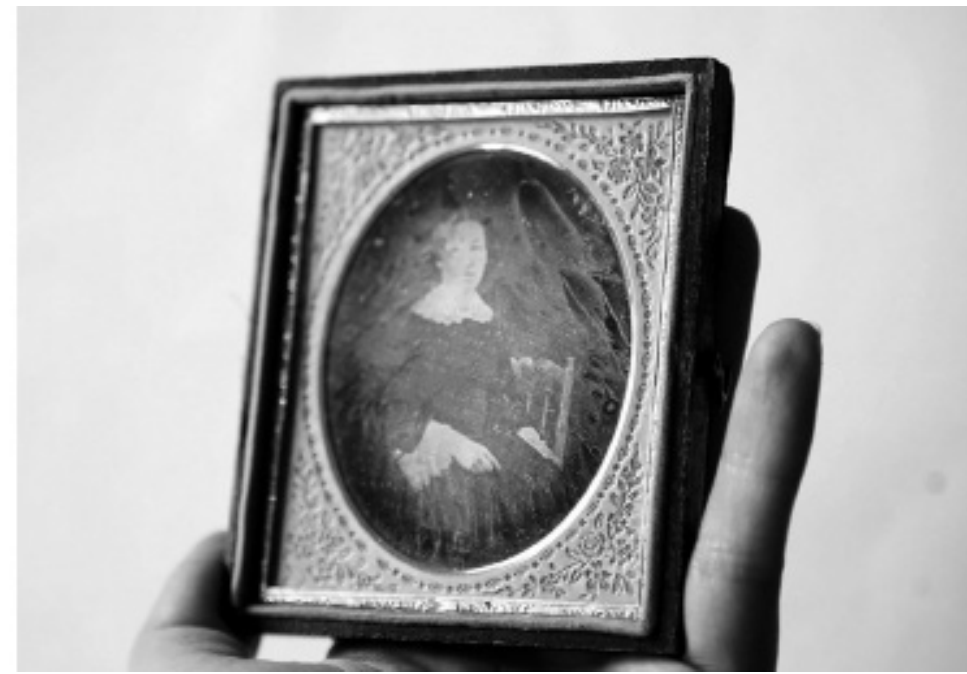

Il. 1. Dagerotyp - fotografia wytworzona w pierwszej technice fotograficznej, w procesie bezpośrednim. Obiekt charakteryzuje lustrzane podłoże, zmiana obrazu z pozytywu na negatyw w zależności od kąta padania światła oraz bogata oprawa w formie szkatułki. Fot. A. Seweryn

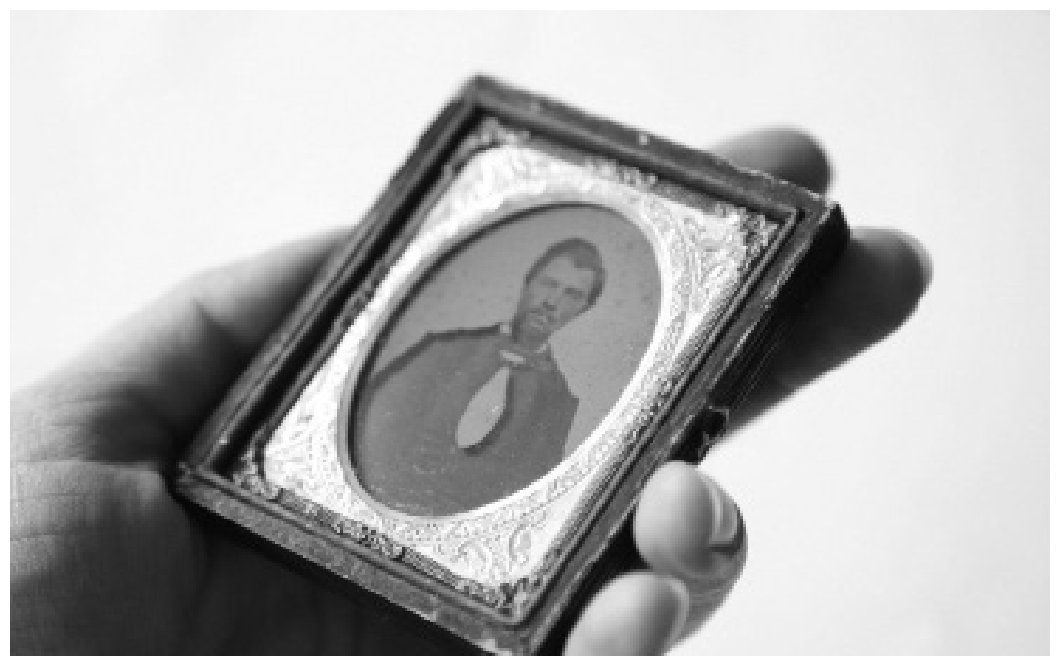

Il. 2. Ambrotyp - fotografia wykonana w procesie bezpośrednim. Podłożem obiektu jest szyba szklana, a obraz wykonany jest na bazie związków srebra i kolodionu. Fot. A. Seweryn 

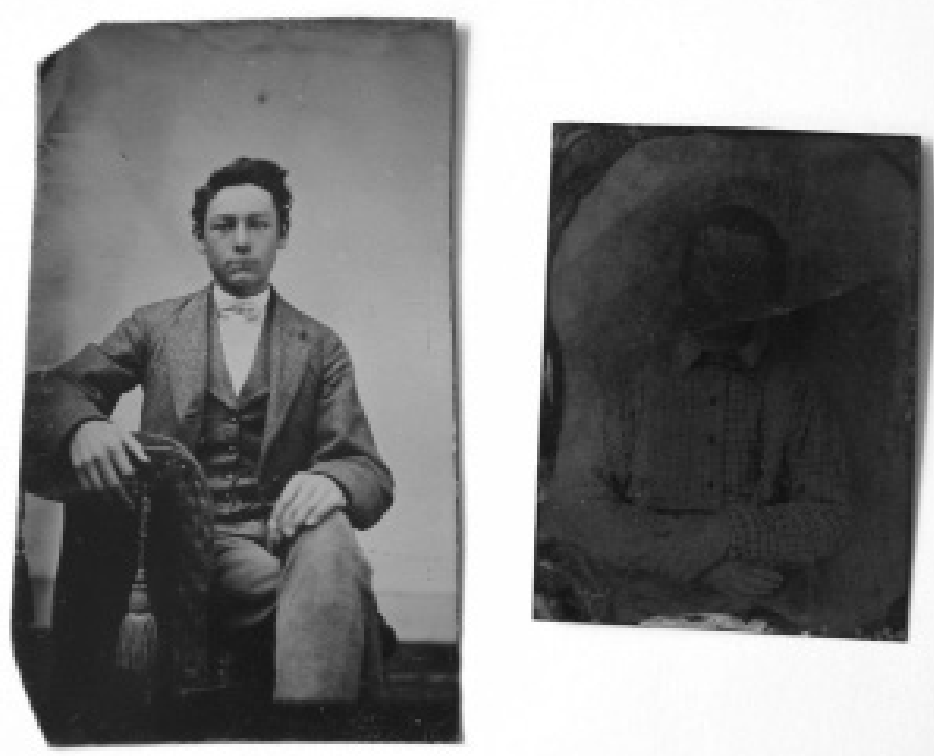

Fot. 3. Ferrotypie-fotografie wytworzone w procesie bezpośrednim na podłożu żelaznym. Obraz podobnie jak w ambrotypii zbudowany jest ze srebra i kolodionu. Fot. A. Seweryn

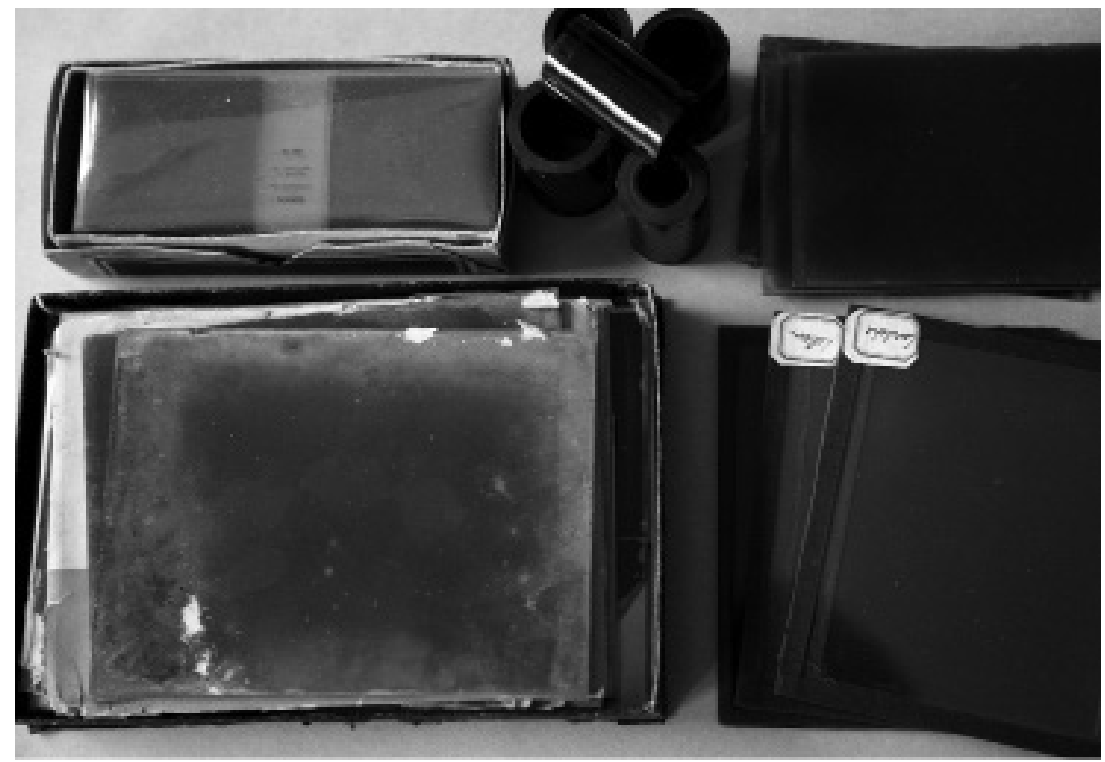

Fot. 4. Przykłady negatywów fotograficznych wykonanych na podłożu szklanym oraz na podłożach z tworzyw sztucznych. Obraz fotograficzny składa się z żelatyny fotograficznej oraz związków srebra. Fot. A. Seweryn 


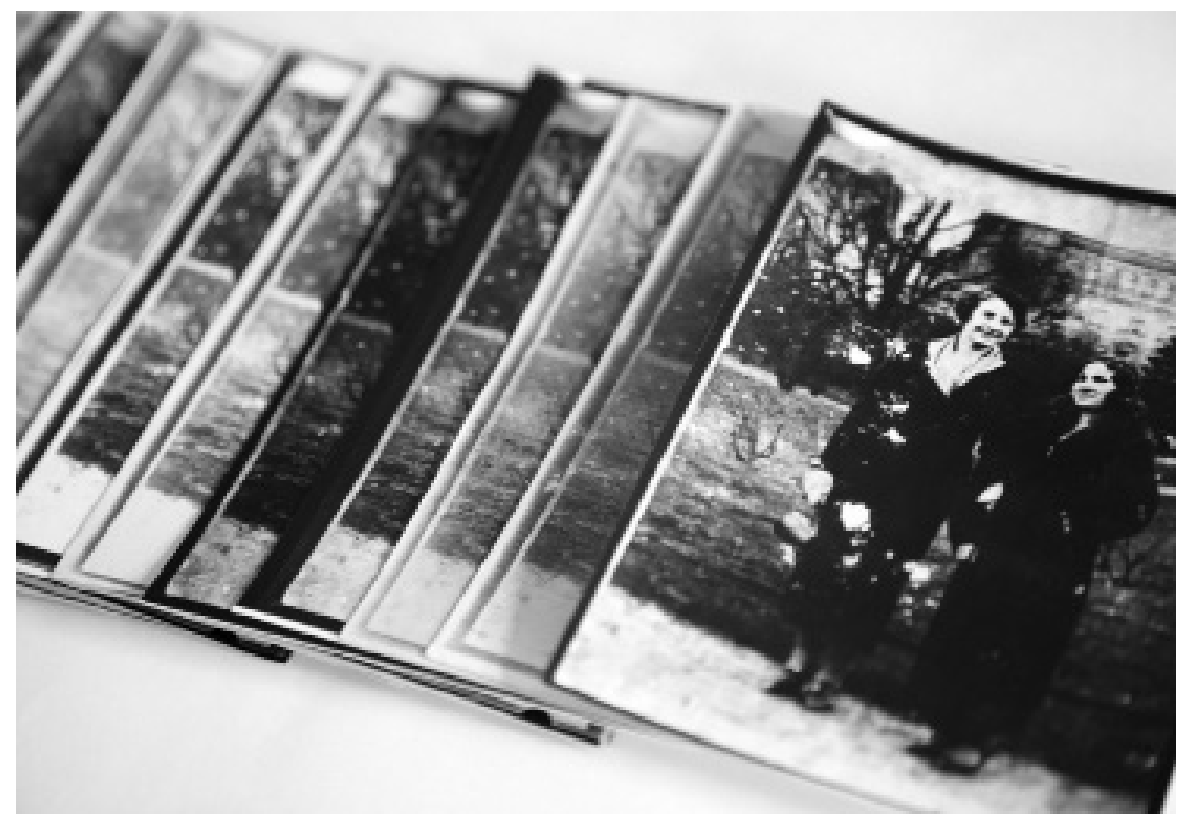

Il. 5. Przykład odbitek fotograficznych wykonanych z jednego negatywu na różnych papierach fotograficznych: papierze solnym, albuminowym, cyjanotypowym oraz żelatynowo-srebrowym. Fot. A. Seweryn

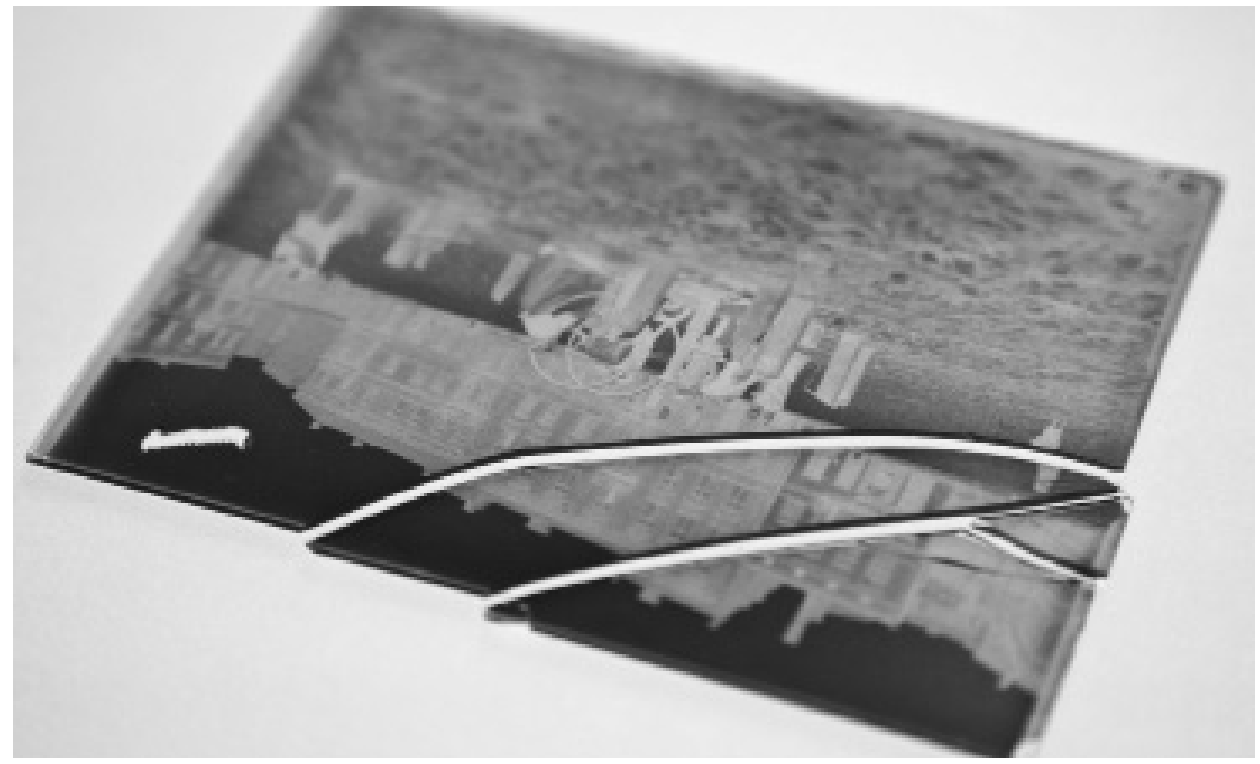

Il. 6. Przykład uszkodzonego mechanicznie negatywu fotograficznego żelatynowo-srebrowego wytworzonego na podłożu szklanym. Fot. A. Seweryn. 


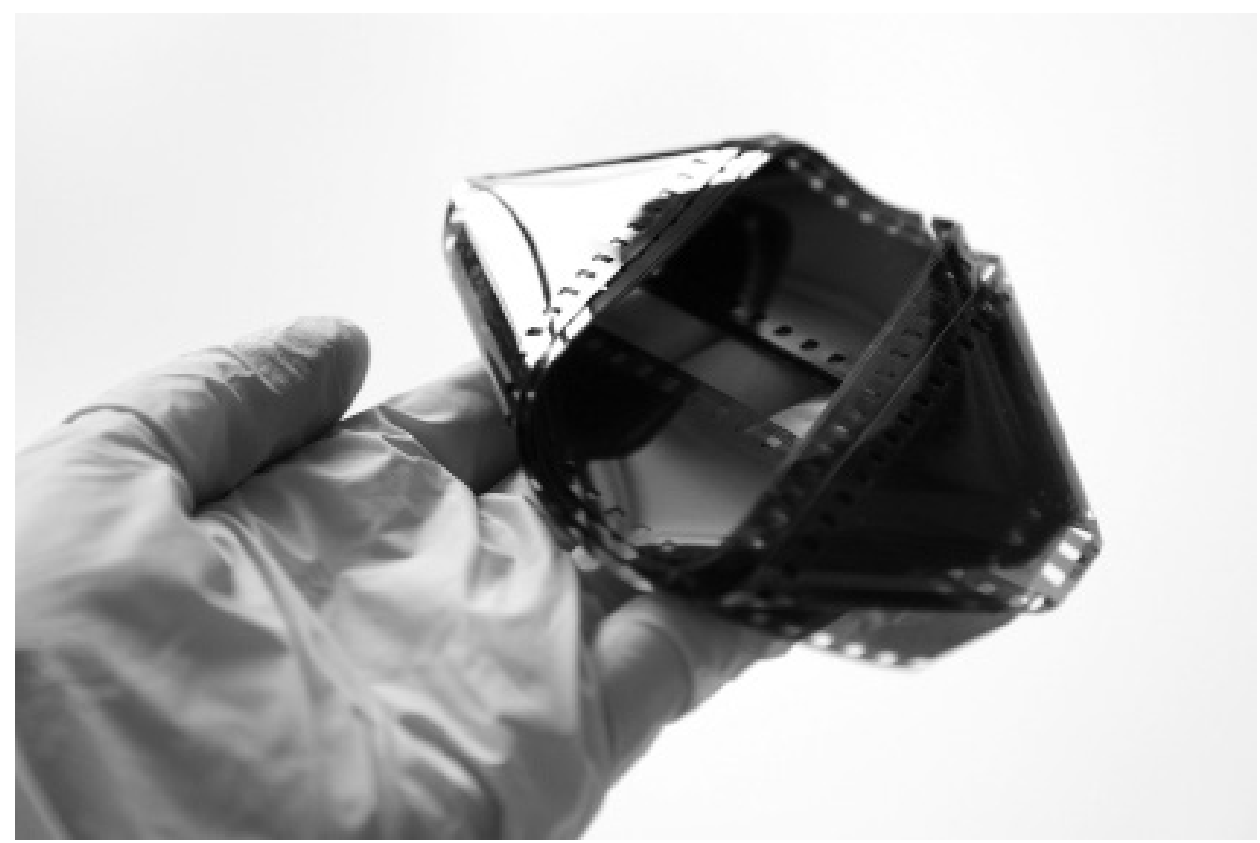

Il. 7. Przykład silnie zdeformowanej błony fotograficznej. Na zniszczenie obiektu wpływ miał niewłaściwy sposób przechowywania. Fot. A. Seweryn

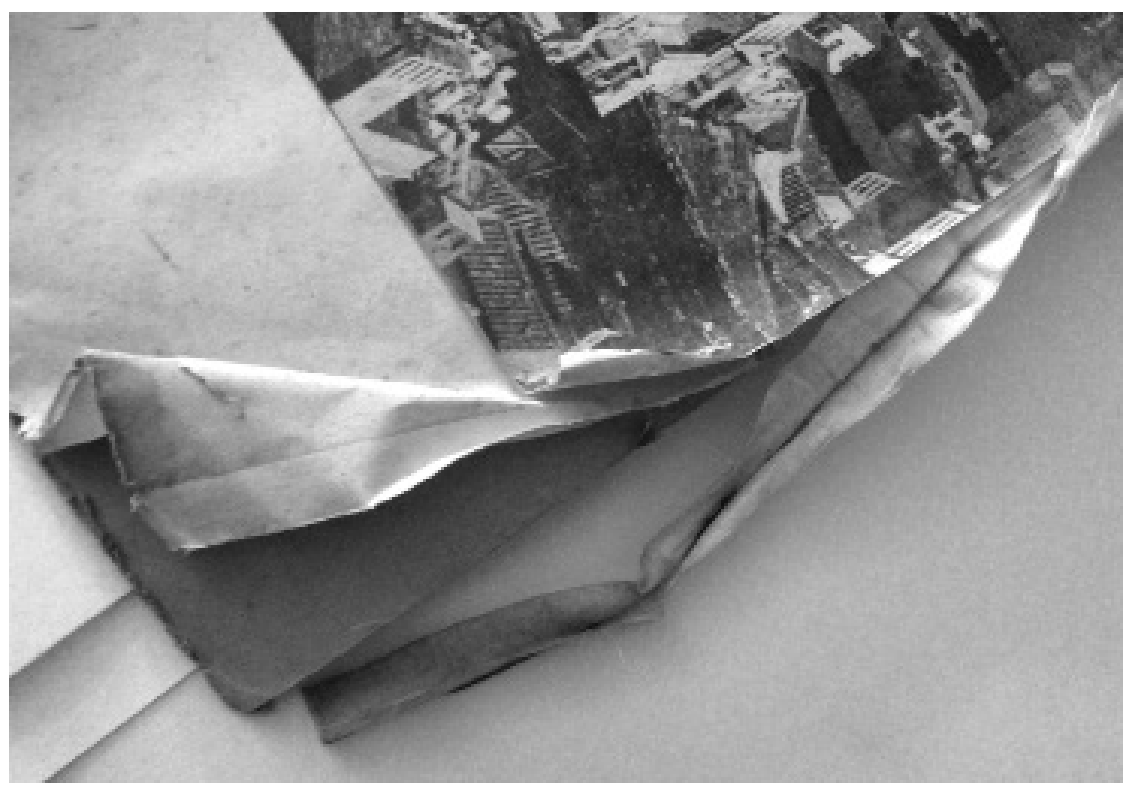

Fot. 8. Przykład zniszczeń mechanicznych w obrębie odbitki fotograficznej. Fot. A. Seweryn 


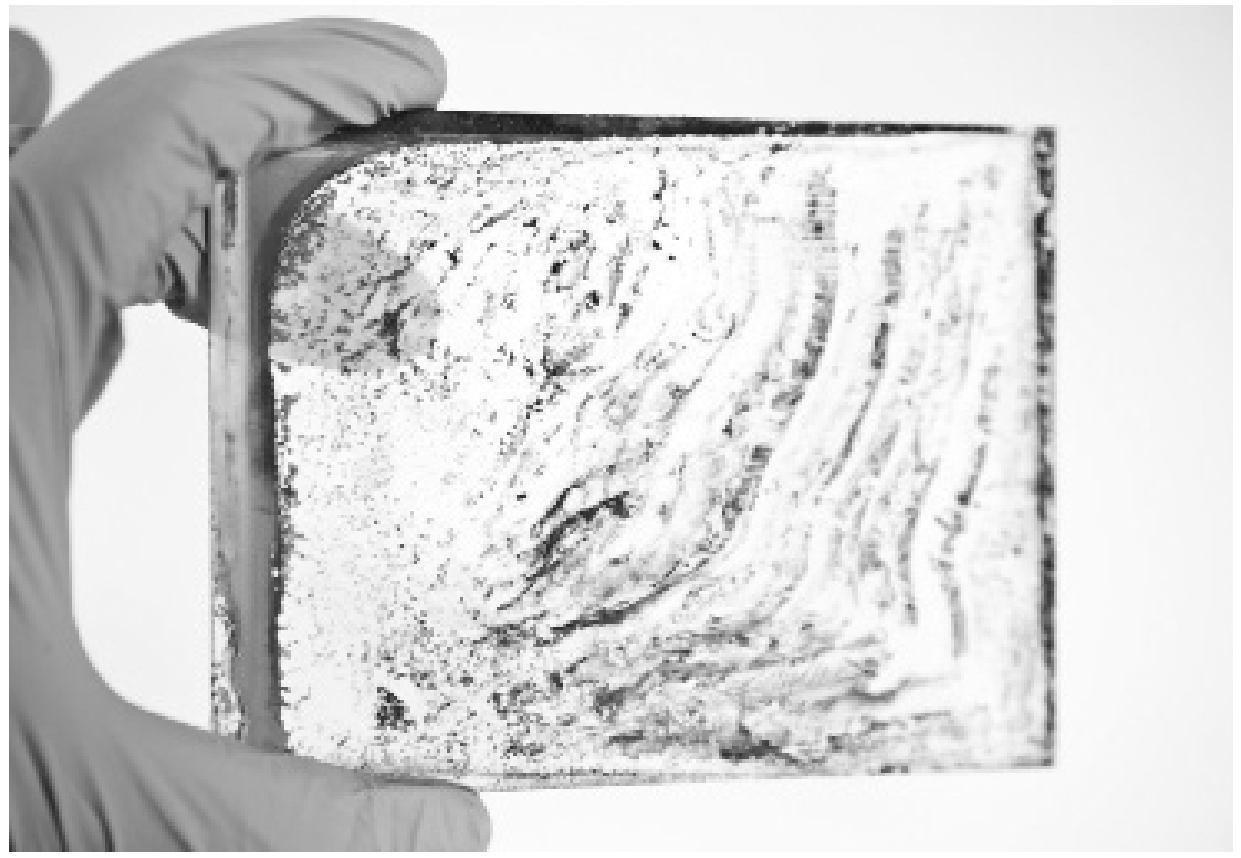

Il. 9. Negatyw żelatynowo-srebrowego na podłożu szklanym po przebytej katastrofie. Działalność wody doprowadziła do całkowitego rozpuszczenia się obrazu zbudowanego na bazie żelatyny. Fot. A. Seweryn

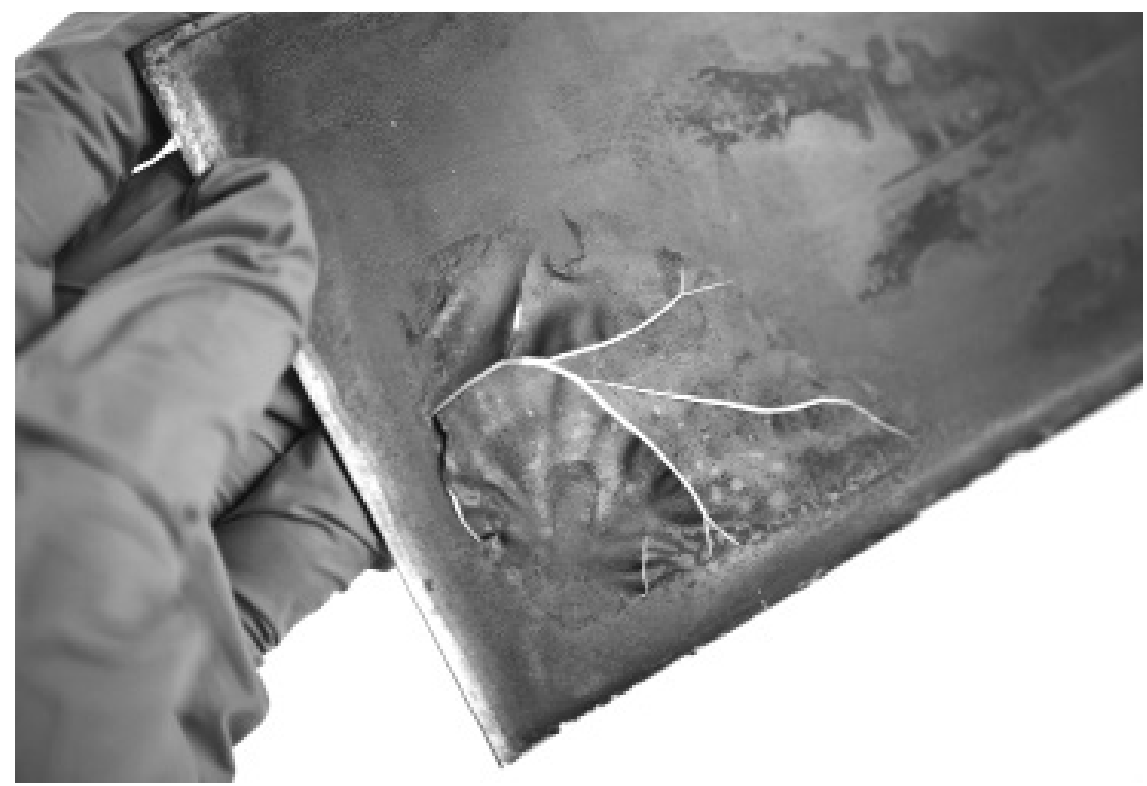

Il. 10. Przykład negatywu żelatynowo-srebrowego o miejscowo odspojonej i uszkodzonej mechanicznie warstwie obrazu. Fot. A. Seweryn 


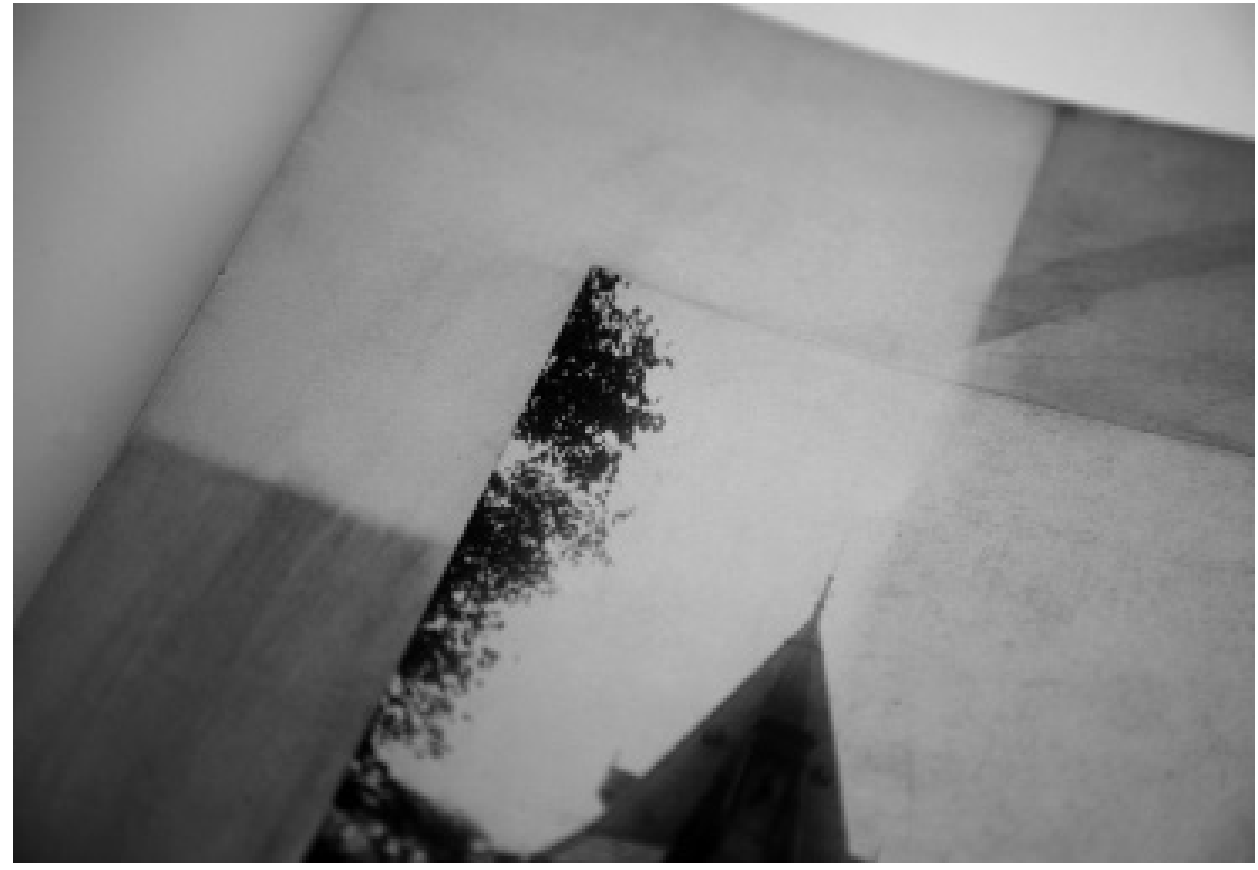

Il. 11. Widoczne efekty mechanicznego oczyszczania odbitki żelatynowo-srebrowej. Fot. A. Seweryn

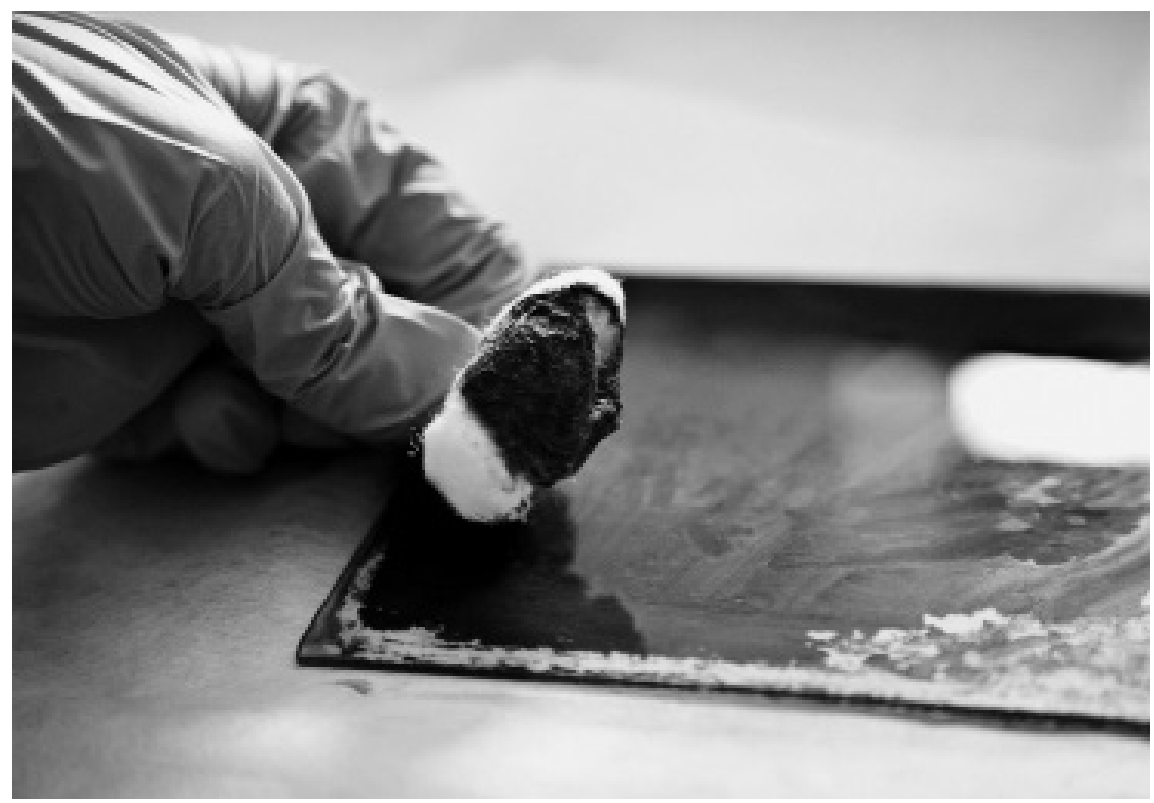

Il. 12. Widoczny proces chemicznego oczyszczania mocno zabrudzonego negatywu żelatynowosrebrowego. Fot. A. Seweryn 


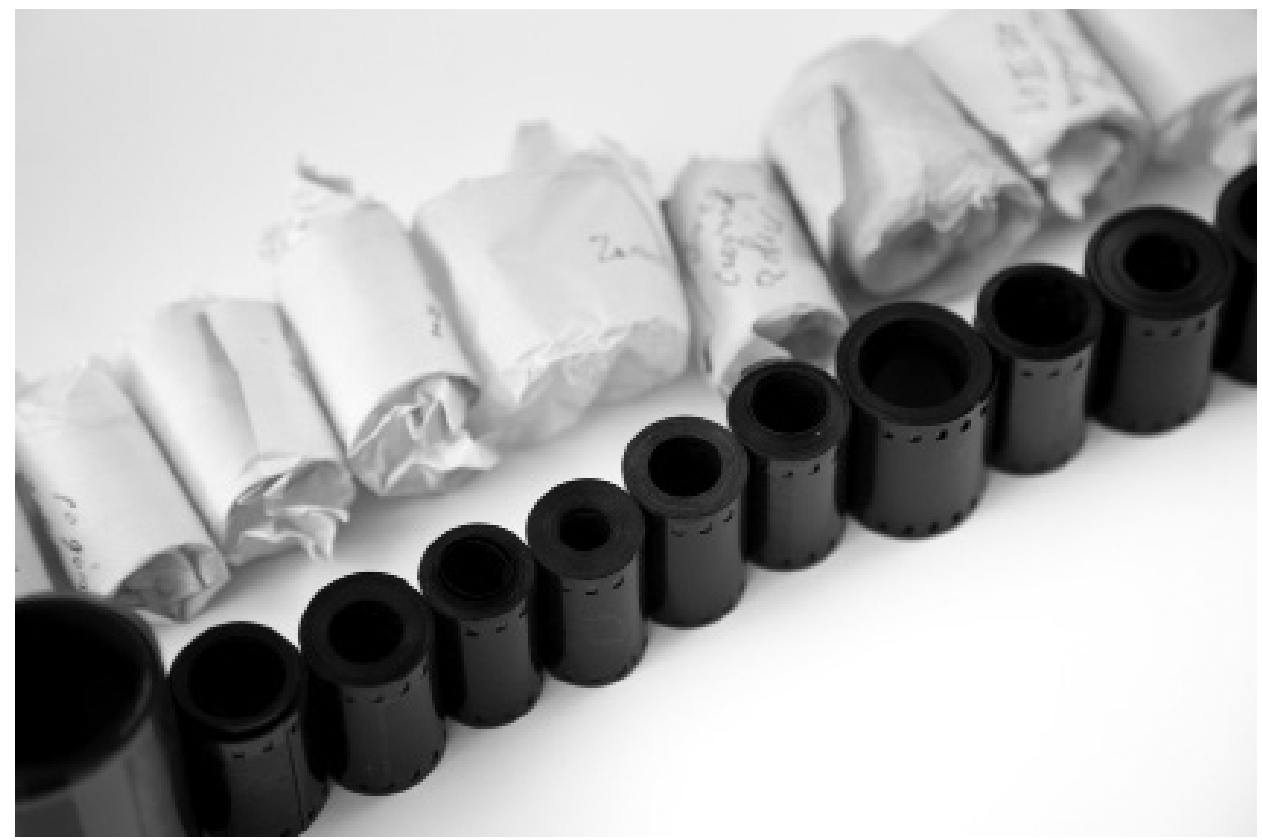

Il 13. Widoczny zespół małoobrazkowych negatywów fotograficznych. Negatywy od chwili ich wytworzenia były przechowywanie w formie zwiniętej, co doprowadziło do znaczących deformacji i uniemożliwiało swobodne rozwinięcie błon. Fot. A. Seweryn

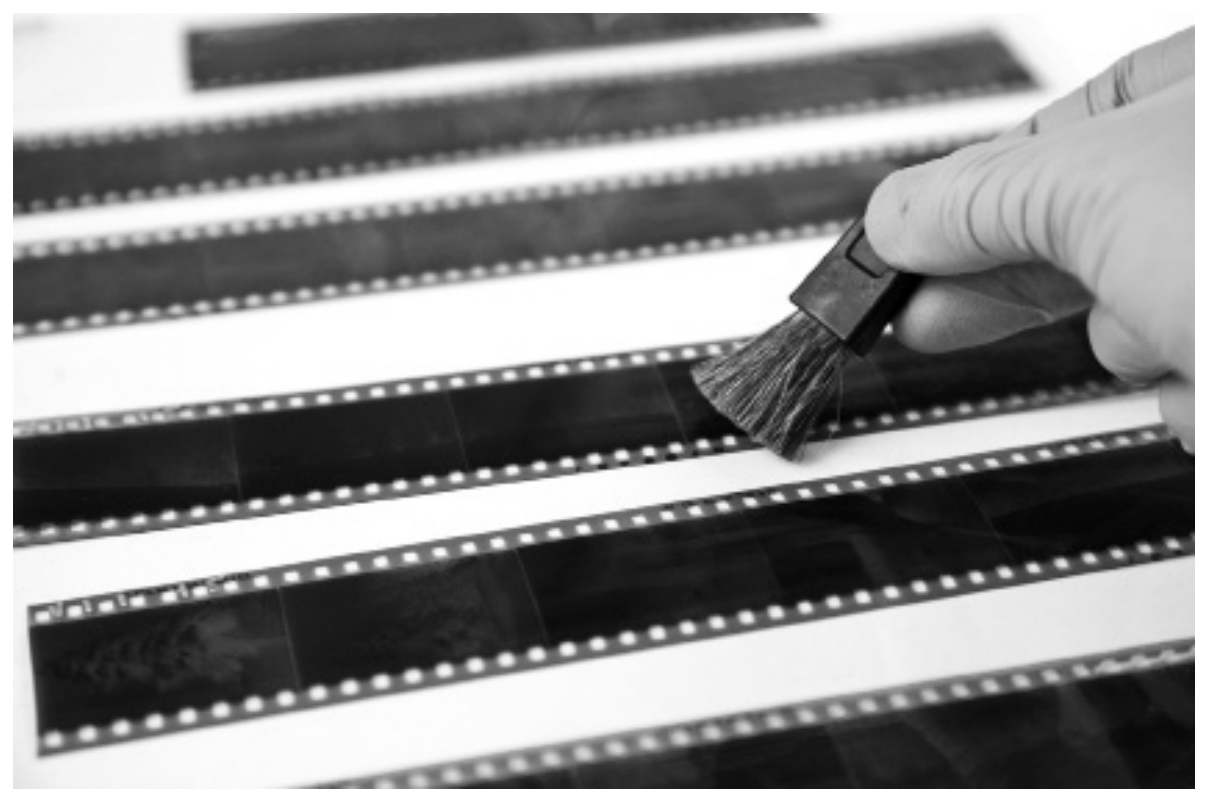

Il. 14. Negatywy małoobrazkowe po procesie prostowania. Fot. A. Seweryn. 


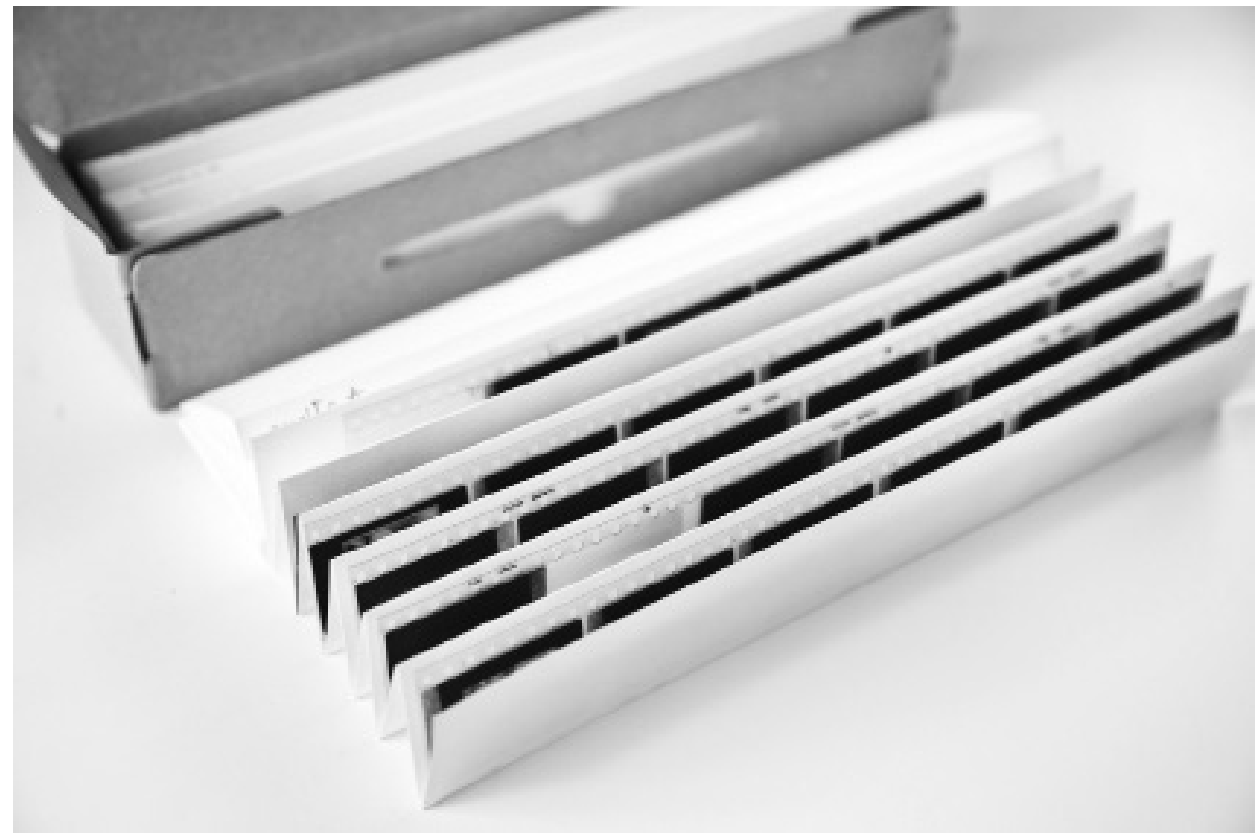

Il. 15. Negatywy małoobrazkowe po procesie konserwacji umieszczone w atestowanym opakowaniu ochronnym-koszulce z papieru bawełnianego o konstrukcji harmonijkowej oraz pudełku zbiorczym. Fot. A. Seweryn

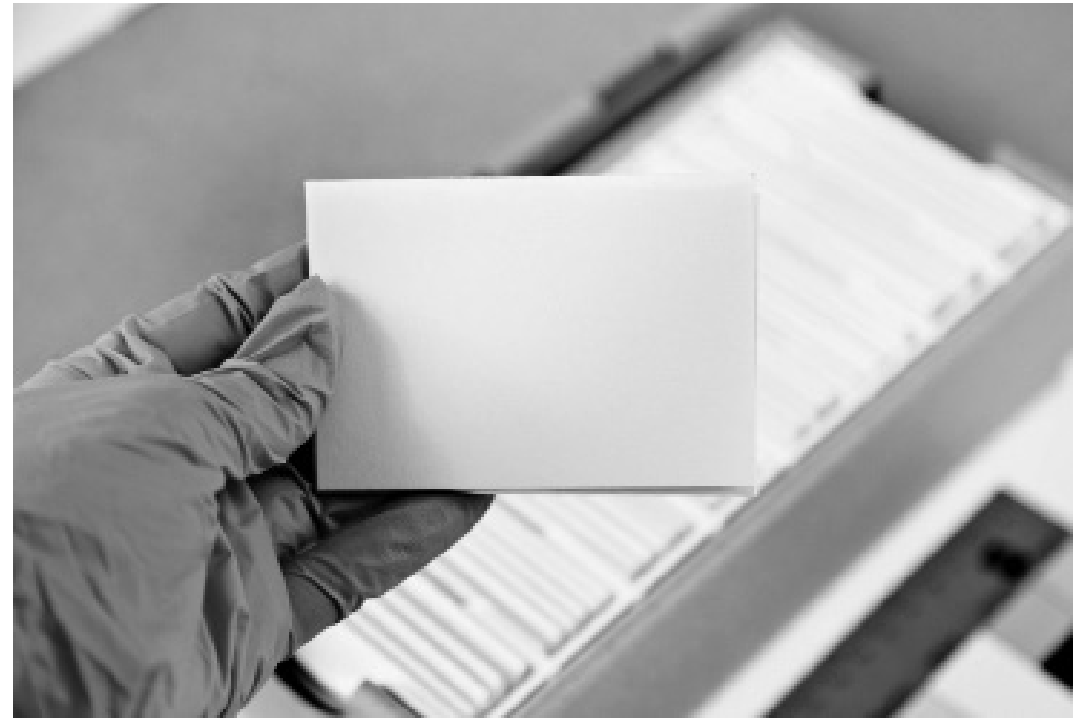

Il. 16. Negatyw żelatynowo-srebrowy na podłożu szklanym zabezpieczony indywidualną koszulką czteroskrzydełkową oraz pudłem zbiorczym. Fot. A. Seweryn 


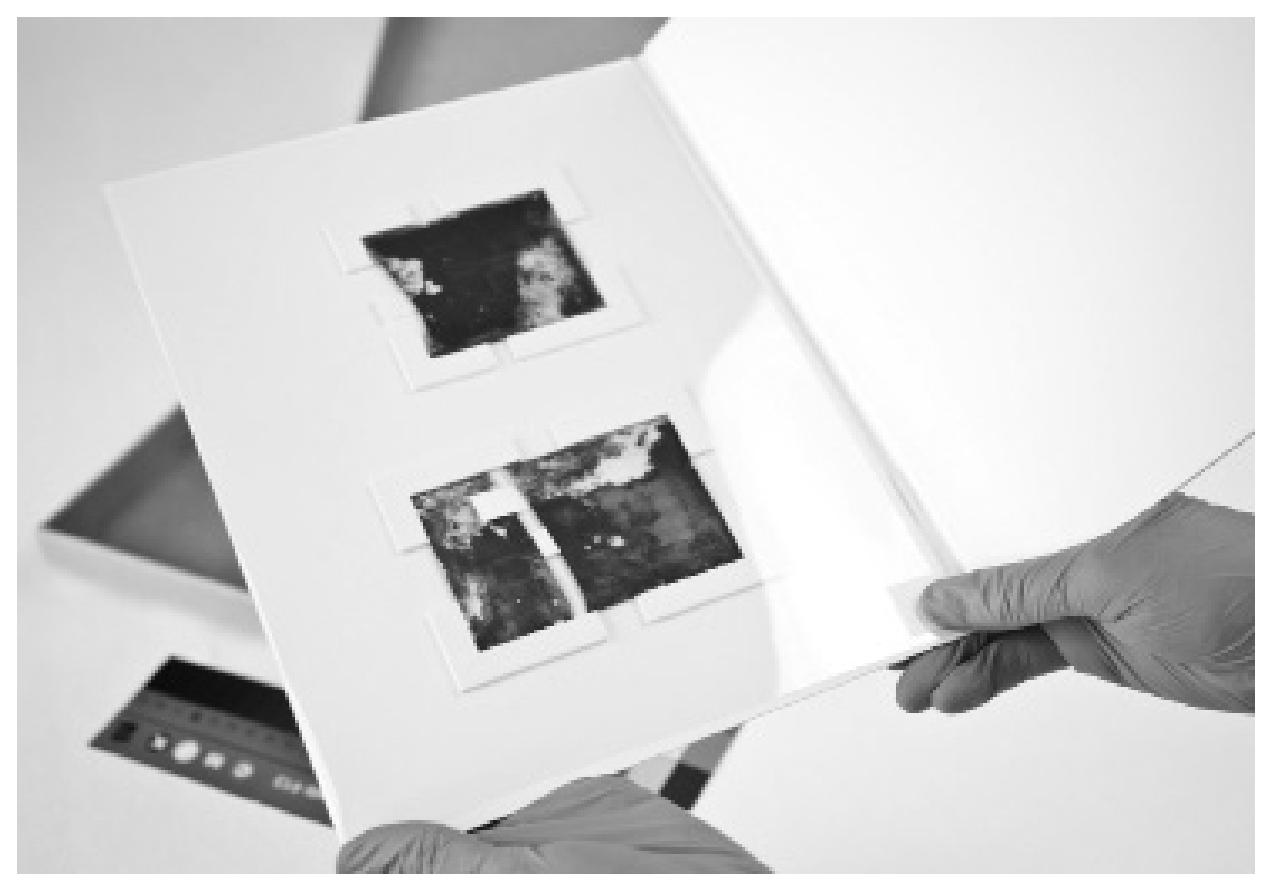

Il. 17. Przykład negatywów żelatynowo-srebrowych na podłożu szklanym uszkodzonych mechanicznie, zabezpieczonych na kartonowej podkładce. Fot. A. Seweryn.

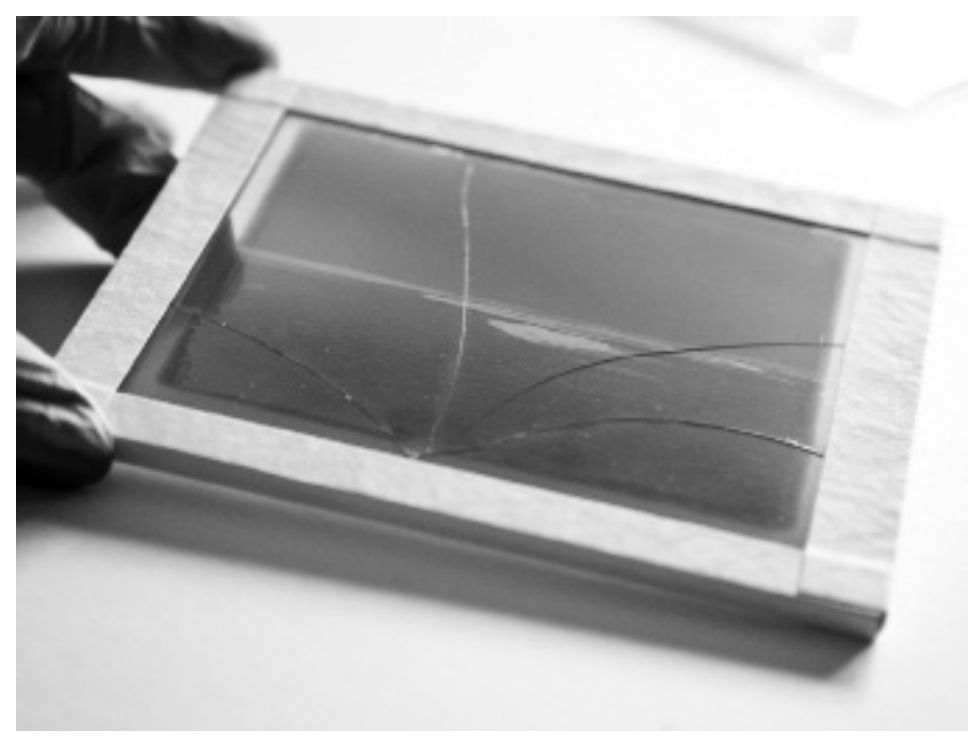

Il. 18. Negatyw żelatynowo-srebrowy na podłożu szklanym uszkodzony mechanicznie, zabezpieczony poprzez umieszczenie go między dwiema szybami szklanymi, tzw. dublaż. Fot. A. Seweryn 


\title{
PHOTOGRAPHY IN ARCHIVE: IDENTIFICATION - PRESERVING - CONSERVATION
}

\begin{abstract}
The article is devoted to the issue of photography as an archival material requiring particular knowledge at the stage of identification, preservation and conservation of collections. Photographs are objects made in various techniques and technologies, on a range of bases and light-sensitive substances. Their complicated structure is responsible for the exceptional sensitivity of these objects in contact with destructive factors and for the often rapid course of the degradation process, even resulting in the complete loss of the medium. The text deals with the identification of techniques and technologies used in the making of objects, describes the factors influencing the degradation of images, and highlights the basic guidelines for the protection and conservation of collections. The text presents the beginnings of the phenomenon of photography, as well as the most common photographic techniques found in Polish collections. The author describes the most important research concerning the identification and preservation of photographs, quoting source materials. The essential part of the study consists of guidelines concerning the process of identification of the technique of taking an object, from which all activities connected with securing or preserving photographs should begin (including the identification of unstable plastic bases). Then the text describes the most common causes of degradation of archival photographic materials and the basic processes thanks to which we can positively influence the longevity of photographic collections (including the storage of objects in reduced temperature and relative humidity parameters). The study ends with a description of preventive conservation measures necessary to maintain the collections in a good state of preservation as well as proper handling of photographs during the process of digitization of the collections.
\end{abstract}

Keywords: archive; photography; identification; conservation; negative; print; preservation 